妥当性評価

\title{
新規自動前処理装置（FASRAC）を用いたGC-MS/MSによる 農産物中の残留農薬一斉試験法の妥当性評価
}

(平成 26 年 2 月 14 日受理)

\author{
奥田大貴* 古志直弘＼cjkstart松村敦山本礼央大柳達也 松田高博 \\ 橋本昭彦＼cjkstart畠山治小林和浩＼cjkstart長尾康博山田敏広
}

Validation Study on a Multi-Residue Method for Determination of Pesticide Residues in Agricultural Products by New Automatic Pretreatment Equipment (FASRAC) and GC-MS/MS

Taiki Okuda*, Naohiro Koshi, Atsushi Matsumura, Reo Yamamoto, Tatsuya Oyanagi, Takahiro Matsuda, Akihiko Hashimoto, Osamu Hatakeyama, Kazuhiro Kobayashi, Yasuhiro Nagao and Toshihiro Yamada

Research Institute of Food Safety, Nissin Foods Holdings Co., Ltd.: 2100-ban, Tobukimachi, Hachioji-shi, Tokyo 192-0001, Japan;

${ }^{*}$ Corresponding author

\begin{abstract}
A validation study was performed on a multiresidue method for determination of pesticide residues in agricultural products according to the method validation guideline of the Ministry of Health, Labour and Welfare of Japan. FASRAC (Food Automatic Analytical Systems for Residual Agricultural Chemicals) automatically performs extraction of pesticide residues from agricultural products with acetonitrile, filtration, constant volume, mixing with the use of air, mixing acetonitrile with buffer solvent, separation, and dehydration with sodium sulfate. The extract was purified with a $\mathrm{GC} / \mathrm{NH}_{2}$ column. For wheat flour and soybeans, a purification step with a $\mathrm{C} 18$ column was added before a $\mathrm{GC} / \mathrm{NH}_{2}$ column. After removal of the solvent, the extract was resolved in $n$-hexane/ acetone solvent for GC-MS/MS analysis. In the case of manual analysis, pesticide residues were analyzed according to official multiresidue methods and purification steps were the same as in FASRAC. Recovery tests were performed with wheat flour, soybeans, spinach and apples, by addition of 302 pesticides at the concentrations $0.01 \mathrm{mg} / \mathrm{kg}$. The results indicate that automatic extraction using FASRAC is superior to manual analysis in trueness, repeatability and within-run reproducibility. Specially, automatic extraction using FASRAC is superior to manual analysis in trueness because it is optimized in various respects, for example reextraction at salting-out.
\end{abstract}

(Received February 14, 2014)

Key words: 残留農薬 pesticide residues; 妥当性評価validation study; ガスクロマトグラフィータン デム型質量分析計 GC-MS/MS; 自動前処理装置 automatic pretreatment equipment; Food Automatic Analytical Systems for Residual Agricultural Chemicals (FASRAC)

\section{緒言}

消費者の食の安全に対する関心は高く, 中国製冷凍餃子 への有機リン系農薬メタミドホスの混入事件, 中国産ホウ レンソウでの有機リン系農薬クロルピリホスの高濃度残留 問題をはじめとして, 現在でも残留農薬に対する関心は極 めて高くなっている.

残留農薬等に関する厳しい基準であるポジティブリスト 制度が 2006 年に施行されて以来, 残留農薬分析では多種

* 連絡先：t-okuda@nissinfoods-holdings.co.jp 日清食品ホールデイングス株式会社食品安全研究所：テ1920001 東京都八王子市戸吹町 2100 番
類の農薬を迅速かつ簡便に，高い精度で多検体分析するこ とが求められている。われわれは新規自動前処理装置 (FASRAC: Food Automatic Analytical Systems for Residual Agricultural Chemicals）を開発し，抽出，万過， 定容, 塩析, 脱水, 濃縮・乾固の一連の工程を公定法に準 拠した操作手順で自動化することに成功した ${ }^{1)}$ 。これによ り, 従来の手作業による前処理と比較して, 作業の効率化 および省力化，作業中のコンタミネーションリスクの低 減，洗浄溶媒の不使用および分析者間における手技の個人 差の低減を実現した。

本報で用いる試料は，穀類として小麦粉，豆類として大 豆，野菜としてほうれん草および果実としてりんごを選択 
し，FASRACを使用した 302 種類の農薬の一斉分析法を 検討した。また，本法の妥当性を平成 22 年 12 月，厚生労 働省通知「食品中に残留する農薬等に関する試験法の妥当 性評価ガイドライン」に基づき，「GC/MSによる農薬等の 一斉試験法（農作物）」(公定法)による手作業と比較する ことにより評価を実施したので報告する.

\section{実 験 方法}

\section{1. 試料および調製}

市場で購入した小麦粉, 大豆, ほうれん草およびりんご を使用した． 食品, 添加物等の規格基準, A一般食品の成 分規格（昭和 34 年厚生省告示第 370 号）で規定されてい る試験部位をフードプロセッサーで均一化し，使用するま でー $20^{\circ} \mathrm{C}$ で冷凍保存した。 なお, 当該試料からは評価対 象農薬が検出されないことを確認した.

\section{2. 試薬}

分析対象は GC-MS/MSで測定可能な 302 農薬とした.

混合標準品として林純薬工業(株) 製PL2005農薬 GC/ MSMix I 〜 VIおび7（20 $\mu \mathrm{g} / \mathrm{mL}$ アトン溶液）を用い た. 混合標準品以外の標準品は和光純薬工業(株), 関東化 学(株), 林純薬工業(株), Riedel-de-Haën社およびDr. Ehrenstorfer GmbH社製の残留農薬分析用標準品または 同等品を用いた，検量線用標準溶液および最終溶解用溶液 へ添加するリン酸トリフェニル (TPP) は関東化学(株)製 を用いた。対象標準品は $1,000 \mu \mathrm{g} / \mathrm{mL}$ となるようにアセト ンで溶解し，標準原液とした，標準原液を $10 \mu \mathrm{g} / \mathrm{mL}$ とな るように混合, アセトンで希釈し, 混合溶液とした。 TPP を $1,000 \mu \mathrm{g} / \mathrm{mL}$ となるようにアセトンで溶解し TPP原液 とし，それをアセトンで $10 \mu \mathrm{g} / \mathrm{mL}$ に希釈して TPP溶液と した，混合標準品および混合溶液を用いて，対象農薬濃度 が $0.005,0.01,0.05,0.1$ および $0.2 \mu \mathrm{g} / \mathrm{mL}$ とるように, さらに各々に対して内部標準物質としてTPP溶液を $0.5 \mu$ $\mathrm{g} / \mathrm{mL}$ となるように混合し，アセトンおよびへキサンで希 釈し（アセトン:ヘキサン = $1: 1$ ), 検量線用標準溶液と した。混合標準品及び混合溶液用いて，0.1 $\mu \mathrm{g} / \mathrm{mL}$ となる ように混合し, アセトニトリルで希釈し, 添加回収試験溶 液とした。 TPP溶液を $0.5 \mu \mathrm{g} / \mathrm{mL}$ となるように混合し，ア セトンおよびへキサンで希釈し（アセトン:ヘキサン= $1: 1)$, 最終溶解用溶液とした.

アセトニトリル，アセトン，トルエンおよびへキサン (残留農薬分析用) はSigma-Aldrich社製を用いた。蒸留 水（液体クロマトグラフィー用）はナカライテスク製を用 いた．塩化ナトリウムおよび無水硫酸ナトリウム（残留農 薬分析用）はSigma-Aldrich社製を用いた。リン酸水素二 カリウム (特級) およびリン酸二水素カリウムは和光純薬 工業 (株)製を用いた。精製用カラムにはグラファイトカー ボン/アミノプロピルシリル化シリカゲル積層 $\left(\mathrm{GC} / \mathrm{NH}_{2}\right)$ カラム $(500 \mathrm{mg} / 500 \mathrm{mg})$ はSUPELCO 社製, オクタデ シルシリル化シリカゲル $(\mathrm{C} 18)$ カラム $(1,000 \mathrm{mg})$ は Waters社製を用いた。

\section{3. 自動前処理装置および分析機器}

\section{1 装置および機器類}

自動前処理装置および分析機器は下記のものを用いた.

自動前処理装置：システム・インスッルメンッ社製 FASRAC

GC: Thermo Scientific 社製 TRACE GC ULTRA MS/MS: Thermo Scientific社製 TSQ QUANTUM XLS

\subsection{FASRAC 仕様および特長}

幅 $2,030 \mathrm{~mm}$, 高さ $1,650 \mathrm{~mm}$, 奥行き $1,060 \mathrm{~mm}$ を有し, PCにより制御をする（Fig. 1)。ホモジナイザー刃は，6 枚刃，刃長 $1 \mathrm{~cm}$ ，シャフト長さ $11 \mathrm{~cm}$ のもを使用してい る。なお，分注器および定容に使用したガラス管の精度は 購入メーカーにおいて, 計量した蒸留水の重量を測定する ことによって保証されている. 抽出カップへの試料の秤 量, 食塩および無水硫酸ナトリウムの科量, 使い捨てチッ プのセットなど各工程での事前準備をする．稼動すると， 工程(1)抽出・ろ過，工程(2)定容・空気吹込みによるバブリ ングかくはん，工程(3スターラーかくはんによる塩析，工 程(4)脱水，工程(5)窒素ガスによる濃縮・乾固の順に自動で 処理が進む。工程(1)では，専用のホモジナイズ管を使用し て抽出操作（3,000 rpm）をし，加圧蓋から空気を送り込 むことにより抽出液が加圧ろ過される，工程(2)では，液面 センサーによる自動定容，その後専用のかくはん針から空 気を吹込むことにより抽出液が均一にかくはんされる．工 程(3)おび(4)では，分液漏斗を使用する代わりにスター ラーによるかくはん操作（1,600 rpm）により塩析し，無 水硫酸ナトリウムを量り入れたグーチ漏斗に抽出液を通液 することにより脱水する. 工程(5)では， $40^{\circ} \mathrm{C}$ 以下で加温 しながら窒素ガスを抽出液に吹きつけることにより溶媒を 除去する.

一度に最大 12 検体を処理することができ，終夜も含めた 24 時間操作が可能で, 1 日に最大 48 検体を処理することが できる、稼動中は人の手を一切必要としないため，人件費 が大幅に削減できる。検体と装置部品の 1 対 1 対応，抽出 液の垂れ防止機構，抽出液分取時の使い捨てチップの使用 などにより，コンタミネーションリスクを低減している.

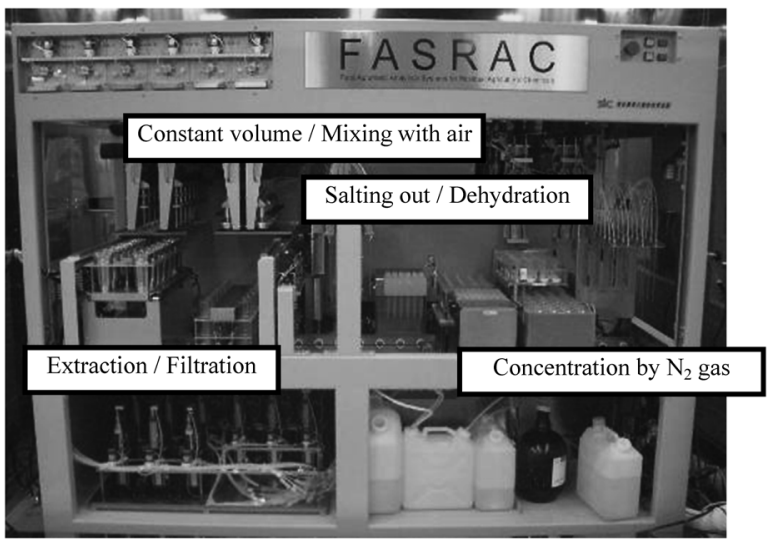

Fig. 1. Components of FASRAC 


\section{4. 分析条件}

\subsection{GC-MS/MS条件}

4.1.1 GC 条件 GC 条件は下記のとおりである.

GC カラム: J\&W Scientific 社製DB-5MS (0.25 mm i.d. $\times$ $30 \mathrm{~m}, 0.25 \mu \mathrm{m})$

カラム温度： $50^{\circ} \mathrm{C}(1 \mathrm{~min}) \rightarrow 25^{\circ} \mathrm{C} / \mathrm{min} \rightarrow 125^{\circ} \mathrm{C}(0 \mathrm{~min}) \rightarrow$ $10^{\circ} \mathrm{C} / \mathrm{min} \rightarrow 300^{\circ} \mathrm{C}(10 \mathrm{~min})$

ガス (流量): $\mathrm{He}(1.0 \mathrm{~mL} / \mathrm{min})$

注入量: $1 \mu \mathrm{L}$

注入口温度： $240^{\circ} \mathrm{C}$

4.1.2 質量分析計条件 質量分析計条件は下記のとお りである.

イオン化電圧： $50 \mathrm{eV}$

イオン化モード：EI $(+)$

インターフェイス温度： $240^{\circ} \mathrm{C}$

イオン源温度： $240^{\circ} \mathrm{C}$

\section{5. 試験溶液の調製}

FASRACを用いた調製および手作業による調製の概要 は Fig. 2 に示す.

\subsection{FASRACを用いた調製}

5.1.1 抽出 小麦粉および大豆は $10.0 \mathrm{~g}$ ，ほうれん草お よびりんごは $20.0 \mathrm{~g}$ を専用のホモジナイズ管に秤量し, 装 置に設置した。以降の操作はFASRACにより自動で抽出 した。

小麦粉および大豆の場合は水 $20 \mathrm{~mL}$ を加え 10 分間放置 した。アセトニトリル $50 \mathrm{~mL}$ 加え，5分間ホモジナイズ 後, 万過し (5分間自然乃過, その後 5 分間加圧ろ過), ガ ラス管に回収した。さらにアセトニトリル $20 \mathrm{~mL}$ を加え, 1 分間ホモジナイズ後，ろ過し（2分間自然ろ過，その後 5 分間加圧ろ過)，同様のガラス管に回収した.

液面センサーを使用し，アセトニトリルで正確に $100 \mathrm{~mL}$ とした。3分間空気を送り込みながら均一にかく はんした。

あらかじめスターラーと塩化ナトリウム $10 \mathrm{~g}$ を量り入 れ， $0.5 \mathrm{~mol} / \mathrm{L} リ ン$ 酸緩衝液 $(\mathrm{pH} 7.0) 20 \mathrm{~mL}$ が注入され たガラス管に抽出液 $20 \mathrm{~mL}$ を分注器で自動注入した。 ス ターラーにより 5 分間かくはん後，5分間静置した。アセ トニトリル層 $15 \mathrm{~mL}$ をらかじめ無水硫酸ナトリウム
FASRAC

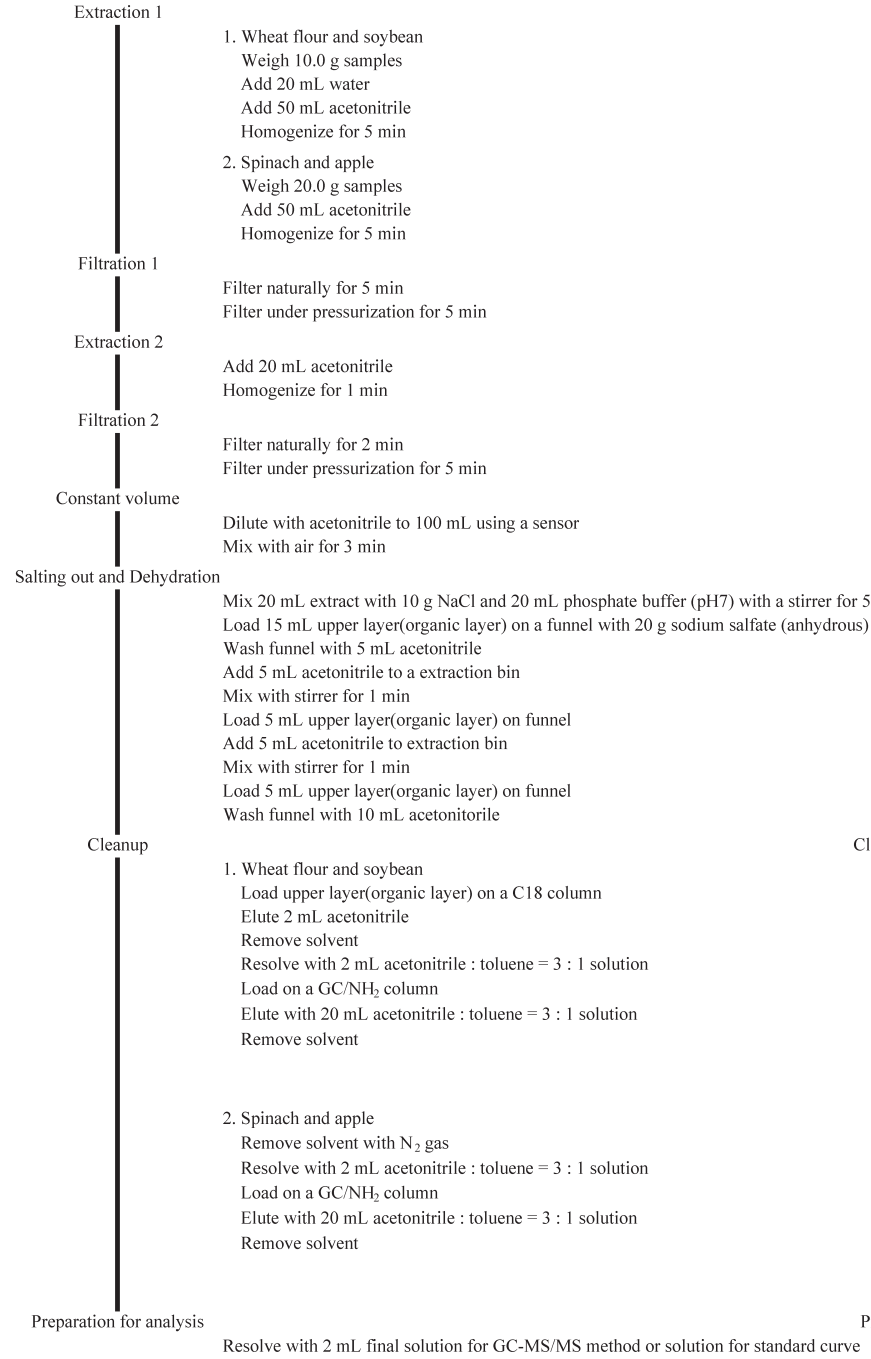

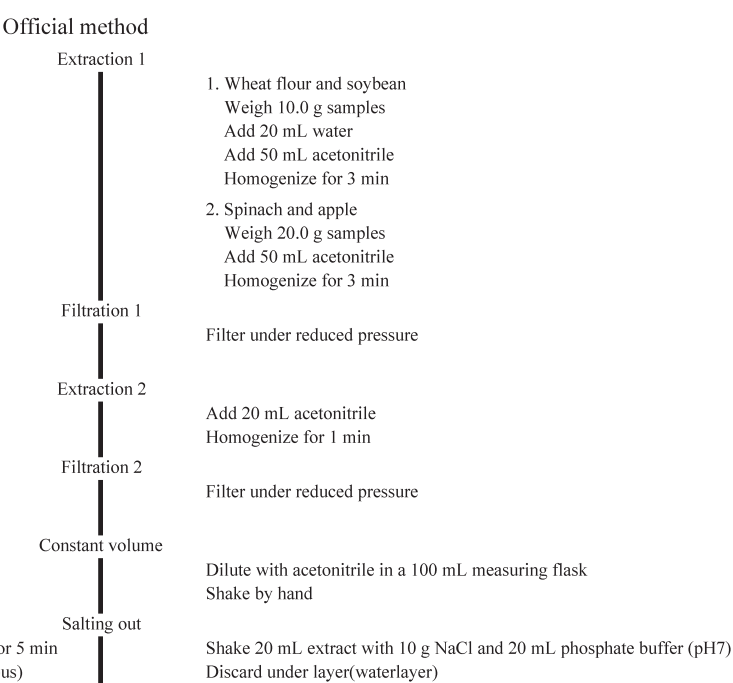
Discard under layer(waterlayer)

Fig. 2. Pretreatment procedures

Wheat flour and soybean Load upper layer(organic layer) on a $\mathrm{C} 18$ column Elute $2 \mathrm{~mL}$ acetonitrile Dehydrate with sodium salfate (anhydrous) Separate extract from sodium sulfate (anhydrous) by filtration Remove solvent

Resolve with $2 \mathrm{~mL}$ acetonitrile : toluene $=3: 1$ solution Load on a $\mathrm{GC} / \mathrm{NH}_{2}$ column

Elute with 20 L Remove solvent

2. Spinach and apple

Dehydrate with sodium salfate (anhydrous) Separate extract from sodium sulfate (anhydrous) by filtration Remove solvent

Resolve with $2 \mathrm{~mL}$ acetonitrile : toluene $=3: 1$ solution Load on a $\mathrm{GC} / \mathrm{NH}_{2}$ column

Elute with $20 \mathrm{~mL}$ acetonitrile : toluene $=3: 1$ solution Remove solvent 
$20 \mathrm{~g}$ を量り入れたグーチ漏斗へ自動注入し, その後アセト ニトリル $5 \mathrm{~mL}$ で無水硫酸ナトリウムを洗浄し，これらの 液は漏斗下部に設置されたガラス管に回収した。アセトニ トリル層を分取したガラス管へアセトニトリル $5 \mathrm{~mL}$ を加 え, スターラーにより 1 分間再度かくはん後, 1 分間静置 した。アセトニトリル層 $5 \mathrm{~mL}$ を再度グーチ漏斗へ自動注 入し, 液は漏斗下部に設置されたガラス管に回収した。ア セトニトリル層を分取したガラス管へ再度アセトニトリル $5 \mathrm{~mL}$ を加え，スターラーにより1分間再度かくはん後， 1 分間静置した。アセトニトリル層 $5 \mathrm{~mL}$ を再度グーチ漏斗 へ自動注入し, その後アセトニトリル $10 \mathrm{~mL}$ で無水硫酸 ナトリウムを洗浄し, これらの液は漏斗下部に設置された ガラス管に回収した。

小麦粉および大豆の場合は, 濃縮・乾固操作は行わず, ほうれん草およびりんごの場合は, 窒素ガスにより抽出液 を $40^{\circ} \mathrm{C}$ 以下で濃縮・乾固した.

5.1 .2 精製 ほうれん草およびりんごの場合は, ガラ ス管にアセトニトリル：トルエン $=3: 1$ 混液 $2 \mathrm{~mL}$ を加え て溶解し, $\mathrm{GC} / \mathrm{NH}_{2}$ カラムへ注入し, アセトニトリル：ト ルエン $=3: 1$ 混液 $20 \mathrm{~mL}$ で溶出した。溶出液は $40^{\circ} \mathrm{C}$ 以下 で濃縮・乾固させた。

小麦粉および大豆の場合は, 抽出液を C18カラムに注 入し,アセトニトリル $2 \mathrm{~mL}$ で溶出した. 濃縮・乾固後, ほうれん草およびりんごの場合と同様に $\mathrm{GC} / \mathrm{NH}_{2}$ カラム により精製した。

5.1.3 最終溶液調製 濃縮・乾固した標準液無添加の 試料 (ブランク試料) および添加回収試験用試料は最終溶 解用溶液を正確に $2 \mathrm{~mL}$ 加え溶解し, 試験溶液とした。濃 縮・乾固したブランク試料に各濃度に調製した検量線用標 準溶液（0.005, 0.01，0.05, 0.1および $0.2 \mu \mathrm{g} / \mathrm{mL} ）$ を正確 に $2 \mathrm{~mL}$ 加え溶解し, 定量に用いた.

\section{2 手作業による調製}

5.2.1 抽出 小麦粉および大豆は $10.0 \mathrm{~g}$, ほうれん草お よびりんごは $20.0 \mathrm{~g}$ をホジナイズ管に秤量した. 小麦粉 および大豆の場合は水 $20 \mathrm{~mL}$ を加え, 15 分間放置した. アセトニトリル $50 \mathrm{~mL}$ を加え，3分間ホモジナイズした 後, 吸引ろ過し, ろ紙上の残留物をアセトニトリル $20 \mathrm{~mL}$ で1分間ホモジナイズ後, 吸引ろ過した。 得られたろ液を アセトニトリルで正確に $100 \mathrm{~mL}$ とした。抽出液 $20 \mathrm{~mL}$ 分取し, 食塩 $10 \mathrm{~g}$ と $0.5 \mathrm{~mol} / \mathrm{L}$ リン酸緩衝液 $(\mathrm{pH} 7.0)$ $20 \mathrm{~mL}$ 加え, 10 分間振とうした。静置後, 水層は廃棄 した。ほうれん草およびりんごの場合はアセトニトリル層 に無水硫酸ナトリウムを加えて脱水し, 無水硫酸ナトリウ ムをろ別した。

5.2 .2 精製 ほうれん草およびりんごの場合は抽出液 を $40^{\circ} \mathrm{C}$ 以下で濃縮・乾固後, アセトニトリル : トルエン = $3: 1$ 混液 $2 \mathrm{~mL}$ に溶解し, $\mathrm{GC} / \mathrm{NH}_{2}$ カラムへ注入し, アセ トニトリル : トルエン $=3: 1$ 混液 $20 \mathrm{~mL}$ で溶出した. 溶出 液は $40^{\circ} \mathrm{C}$ 以下で濃縮・乾固させた。

小麦粉および大豆の場合は, 抽出液を C18カラムに注
入し，アセトニトリル $2 \mathrm{~mL}$ で溶出した。溶出液に無水硫 酸ナトリウムを加えて脱水し，無水硫酸ナトリウムをろ別 した，ろ液を濃縮・乾固後，ほうれん草およびりんごの場 合と同様に $\mathrm{GC} / \mathrm{NH}_{2}$ カラムにより精製した。

5.2.3 最終溶液調製 FASRACを用いた調製時と同様 に最終溶液調製をし，各試料溶液を作製した。

\section{3 枝分かれ実験（添加回収試験）}

FASRACを用いた調製，手作業による調製ともに，対 象 302 農薬について, 一律基準濃度である $0.01 \mathrm{mg} / \mathrm{kg}$ で の添加回収試験を実施者 2 名 2 併行 3 日間で実施し, 選択 性，真度，併行精度および室内精度を評価した。

なお，ガイドラインでは一斉分析法の各試験対象である 農薬の基準值が異なるために基準值濃度の添加が困難な場 合にあっては，「各農薬等の基準值に近い一定の濃度」お よび「一律基準濃度」の2濃度としてもよいと示されてい るが，基準值に近い一定濃度の設定が困難であり，原則は 基準值であるため, 一律基準濃度である $0.01 \mathrm{mg} / \mathrm{kg}, 1$ 濃 度での妥当性評価を行った。

\section{結果および考察}

\section{1. 妥当性評価}

\section{1 選択性および定量限界}

両分析法において選択性を評価するため，小麦粉，大 豆，ほうれん草およびりんご各々のブランク試料を各分析 方法で測定したところ，すべての物質において定量を妨害 するピークはなく，選択性の目標值に適合した。また両分 析法において定量限界を評価するため，ブランク試料に $0.01 \mu \mathrm{g} / \mathrm{mL}$ 検量線用標準溶液を正確に $2 \mathrm{~mL}$ 加え溶解し測 定したところ, 必要なすべての対象農薬は $S / N$ 比が 10 以 上に適合した。

\section{2 真度, 併行精度および室内精度}

妥当性評価ガイドラインに従って，真度，併行精度およ び室内精度の評価を実施した。各分析対象農薬の MRM 条 件, 保持時間, 真度, 併行精度および室内精度はTable 1, 農薬数で整理したものを Table 2 に示す.

試料調製をFASRACで実施した場合，小麦粉 285 農薬， 大豆 278 農薬，ほうれん草 284 農薬およびりんご 284 農薬 が目標值である真度 $(70 \sim 120 \%)$ ，併行精度（RSD\%< $25 \%$ ）および室内精度（RSD\%<30\%）に適合した。

試料調製を手作業で実施した場合，小麦粉 273 農薬，大 豆 229 農薬，ほうれん草 281 農薬およびりんご 283 農薬が 目標值である真度 $(70 \sim 120 \%)$ ，併行精度（RSD\%< $25 \%$ ）および室内精度（RSD\%<30\%）に適合した。

\section{FASRAC と手作業の比較}

小麦粉，ほうれん草およびりんごに対する目標值である 真度 $(70 \sim 120 \%)$ ，併行精度（RSD\%<25\%）および室 内精度（RSD\%<30\%）に適合した農薬はほぼ同数であ り，FASRACで実施した分析法と手作業で実施した分析 法（公定法）は同等であると評価された。 大豆ではFASRAC を用いた前処理において 278 農薬が目標值である真 
Table 1. Comparison table of

\begin{tabular}{|c|c|c|c|c|c|c|c|c|c|c|c|c|}
\hline \multirow{3}{*}{ No. } & \multirow{3}{*}{ Pesticides } & \multirow{3}{*}{$\begin{array}{c}\text { MRM } \\
\text { transitions } \\
\quad(m / z)\end{array}$} & \multirow{3}{*}{$\begin{array}{c}\mathrm{RT} \\
(\mathrm{min})\end{array}$} & \multicolumn{9}{|c|}{ FASRAC } \\
\hline & & & & \multicolumn{3}{|c|}{ Wheat flour } & \multicolumn{3}{|c|}{ Soy beans } & & Spinach & \\
\hline & & & & $\begin{array}{c}\text { Recovery } \\
(\%)\end{array}$ & $\begin{array}{c}\mathrm{RSD}_{1}^{*} \\
(\%)\end{array}$ & $\begin{array}{c}\mathrm{RSD}_{2}^{* *} \\
(\%)\end{array}$ & $\begin{array}{c}\text { Recovery } \\
(\%)\end{array}$ & $\begin{array}{c}\mathrm{RSD}_{1}^{*} \\
(\%)\end{array}$ & $\begin{array}{c}\mathrm{RSD}_{2}^{* *} \\
(\%)\end{array}$ & $\begin{array}{c}\text { Recovery } \\
(\%)\end{array}$ & $\begin{array}{c}\mathrm{RSD}_{1}{ }^{*} \\
(\%)\end{array}$ & $\begin{array}{c}\mathrm{RSD}_{2}^{* *} \\
(\%)\end{array}$ \\
\hline 1 & 2-(1-Naphthyl) acetamide & $185>141$ & 13.9 & 90.8 & 4.3 & 9.2 & 86.4 & 3.1 & 4.4 & 82.8 & 4.1 & 4.4 \\
\hline 2 & 2,6-Dichlorobenzamide & $189>173$ & 11.0 & 81.9 & 4.1 & 10.7 & 83.3 & 5.5 & 8.0 & 80.7 & 7.4 & 7.4 \\
\hline 3 & 2,6-Diisopropylnaphthalene & $212>197$ & 11.7 & 77.1 & 6.1 & 15.5 & 61.1 & 4.5 & 19.8 & 78.4 & 3.9 & 7.7 \\
\hline 4 & 2-Phenylphenol & $170>169$ & 9.5 & 81.3 & 6.8 & 7.3 & 74.1 & 5.4 & 11.5 & 81.9 & 3.0 & 6.2 \\
\hline 5 & Acephate & $136>94$ & 8.4 & 70.7 & 5.7 & 11.3 & 74.0 & 5.2 & 14.1 & 50.7 & 7.8 & 14.3 \\
\hline 6 & Acetochlor & $223>132$ & 13.2 & 84.7 & 9.3 & 11.0 & 79.8 & 7.0 & 12.7 & 84.5 & 6.0 & 7.0 \\
\hline 7 & Acrinathrin & $181>152$ & 19.7 & 106.4 & 2.2 & 25.3 & 88.5 & 2.9 & 4.5 & 72.5 & 4.8 & 15.2 \\
\hline 8 & Alachlor & $188>160$ & 13.4 & 81.2 & 7.2 & 11.6 & 76.3 & 7.5 & 7.5 & 81.2 & 5.9 & 8.9 \\
\hline 9 & Aldrin & $263>193$ & 14.3 & 71.2 & 13.7 & 14.9 & 64.1 & 18.2 & 18.2 & 80.0 & 12.7 & 12.7 \\
\hline 10 & Allethrin & $367>213$ & 15.0 & 85.0 & 10.5 & 16.6 & 88.1 & 16.6 & 16.6 & 79.0 & 8.1 & 10.6 \\
\hline 11 & Allidochlor & $132>56$ & 6.9 & 76.4 & 4.1 & 7.6 & 74.1 & 3.1 & 9.2 & 70.6 & 3.1 & 8.3 \\
\hline 12 & Ametryn & $227>170$ & 13.6 & 84.3 & 6.2 & 15.7 & 80.4 & 8.6 & 12.0 & 83.2 & 9.4 & 9.7 \\
\hline 13 & Aminocarb & $151>136$ & 12.1 & 83.3 & 4.8 & 11.3 & 71.4 & 10.8 & 13.4 & 82.9 & 6.0 & 6.6 \\
\hline 14 & Atrazine & $215>200$ & 11.9 & 76.0 & 6.9 & 20.0 & 86.1 & 8.4 & 11.0 & 82.7 & 3.2 & 6.1 \\
\hline 15 & Azaconazole & $217>173$ & 16.4 & 81.7 & 2.4 & 9.9 & 82.6 & 3.0 & 5.4 & 83.8 & 3.5 & 6.1 \\
\hline 16 & Azinphos ethyl & $160>77$ & 19.9 & 88.0 & 2.5 & 10.9 & 82.9 & 3.3 & 4.3 & 81.6 & 4.0 & 5.9 \\
\hline 17 & Benalaxyl & $266>148$ & 17.4 & 83.7 & 8.3 & 12.8 & 82.1 & 8.3 & 10.5 & 86.9 & 6.0 & 6.6 \\
\hline 18 & Benfluralin & $292>264$ & 11.0 & 87.7 & 5.2 & 10.1 & 82.8 & 3.6 & 8.2 & 74.4 & 5.0 & 6.0 \\
\hline 19 & Benfuresate & $163>121$ & 13.1 & 86.8 & 9.4 & 16.0 & 93.5 & 6.1 & 7.9 & 86.1 & 10.4 & 11.1 \\
\hline 20 & Benoxacor & $259>120$ & 12.9 & 85.4 & 4.8 & 10.9 & 93.1 & 7.3 & 8.2 & 83.2 & 5.4 & 5.7 \\
\hline 21 & Bifenox & $341>310$ & 18.9 & 87.1 & 9.7 & 14.6 & 89.7 & 7.7 & 8.7 & 75.1 & 9.6 & 9.6 \\
\hline 22 & Bifenthrin & $181>166$ & 18.5 & 84.2 & 3.7 & 8.3 & 75.6 & 2.4 & 5.2 & 76.7 & 3.3 & 5.0 \\
\hline 23 & Bitertanol & $170>141$ & 20.3 & 86.3 & 1.6 & 9.0 & 80.8 & 2.3 & 6.4 & 82.6 & 3.8 & 8.3 \\
\hline 24 & Bromacil & $205>188$ & 13.9 & 84.7 & 8.6 & 14.1 & 83.9 & 4.0 & 6.9 & 80.8 & 5.2 & 5.2 \\
\hline 25 & Bromobutide & $232>176$ & 13.3 & 76.0 & 12.4 & 16.9 & 80.4 & 10.0 & 11.3 & 81.8 & 7.8 & 11.8 \\
\hline 26 & Bromoconazole & $295>175$ & 18.5 & 85.5 & 4.8 & 7.8 & 81.7 & 4.1 & 8.7 & 82.1 & 6.1 & 6.1 \\
\hline 27 & Bromophos ethyl & $359>303$ & 15.4 & 82.2 & 6.8 & 9.1 & 75.7 & 6.8 & 6.8 & 79.6 & 9.5 & 10.0 \\
\hline 28 & Bromophos methyl & $331>316$ & 14.6 & 87.0 & 5.4 & 10.5 & 83.8 & 6.8 & 6.8 & 82.9 & 5.5 & 5.9 \\
\hline 29 & Bromopropylate & $341>183$ & 18.6 & 86.6 & 3.7 & 6.8 & 75.5 & 5.4 & 5.4 & 81.1 & 5.5 & 5.5 \\
\hline 30 & Butachlor & $237>160$ & 15.6 & 85.6 & 6.0 & 9.5 & 78.1 & 6.3 & 15.2 & 80.7 & 6.0 & 10.6 \\
\hline 31 & Butamifos & $286>202$ & 15.8 & 78.9 & 11.5 & 17.0 & 79.6 & 7.4 & 9.2 & 77.7 & 7.0 & 7.9 \\
\hline 32 & Butralin & $266>190$ & 14.5 & 85.3 & 8.8 & 11.4 & 78.9 & 10.2 & 11.1 & 75.6 & 7.0 & 8.2 \\
\hline 33 & Butylate & $156>57$ & 8.4 & 72.5 & 5.8 & 8.4 & 64.4 & 5.0 & 15.5 & 67.3 & 4.9 & 6.2 \\
\hline 34 & Cadusafos & $159>97$ & 11.2 & 82.8 & 3.8 & 6.1 & 79.6 & 3.7 & 5.9 & 78.4 & 5.8 & 7.9 \\
\hline 35 & Carbetamide & $119>91$ & 14.5 & 95.4 & 13.3 & 13.3 & 78.8 & 8.9 & 20.0 & 88.1 & 6.9 & 15.3 \\
\hline 36 & Carbophenothion & $342>157$ & 17.5 & 90.7 & 6.3 & 8.2 & 77.0 & 7.9 & 9.3 & 76.9 & 8.6 & 11.3 \\
\hline 37 & Carbosulfan & $163>135$ & 18.4 & 41.8 & 25.8 & 35.1 & 52.7 & 16.1 & 16.4 & 62.6 & 8.1 & 12.1 \\
\hline 38 & Chlomethoxynil & $266>218$ & 17.9 & 85.5 & 5.0 & 9.5 & 76.8 & 4.0 & 6.9 & 79.6 & 3.0 & 4.6 \\
\hline 39 & Chlorbenside & $268>125$ & 15.5 & 79.4 & 5.4 & 10.2 & 62.5 & 6.8 & 12.5 & 76.3 & 6.5 & 6.7 \\
\hline 40 & Chlorbufam & $223>127$ & 11.9 & 89.0 & 11.1 & 11.7 & 78.0 & 7.4 & 11.9 & 79.1 & 5.3 & 7.4 \\
\hline 41 & Chlordimeform & $196>181$ & 10.9 & 80.4 & 11.3 & 12.5 & 81.7 & 4.0 & 6.0 & 77.4 & 7.7 & 7.7 \\
\hline 42 & Chlorethoxyphos & $153>97$ & 10.5 & 81.6 & 1.8 & 8.9 & 76.3 & 3.0 & 9.6 & 74.8 & 3.9 & 3.9 \\
\hline 43 & Chlorfenapyr & $247>227$ & 16.4 & 92.0 & 11.1 & 15.6 & 72.8 & 19.0 & 24.2 & 81.9 & 19.6 & 19.6 \\
\hline 44 & Chlorfenson & $304>111$ & 16.0 & 85.6 & 15.4 & 17.2 & 81.1 & 13.8 & 17.1 & 84.0 & 13.2 & 13.9 \\
\hline 45 & Chlormephos & $234>121$ & 8.5 & 73.7 & 5.2 & 11.1 & 71.1 & 2.7 & 13.1 & 70.8 & 5.3 & 6.6 \\
\hline 46 & Chlornitrofen & $317>236$ & 17.4 & 88.1 & 13.8 & 15.5 & 83.5 & 6.8 & 9.0 & 80.3 & 6.6 & 8.5 \\
\hline 47 & Chlorobenzilate & $251>139$ & 16.8 & 84.0 & 2.7 & 10.1 & 78.3 & 2.6 & 5.8 & 79.5 & 3.2 & 5.3 \\
\hline 48 & Chloroneb & $193>113$ & 9.3 & 75.8 & 6.0 & 11.9 & 75.2 & 4.6 & 13.5 & 78.5 & 4.3 & 5.3 \\
\hline 49 & Chlorpropham & $213>171$ & 10.9 & 82.4 & 6.8 & 8.5 & 78.5 & 5.2 & 9.2 & 80.1 & 5.2 & 6.1 \\
\hline 50 & Chlorpyrifos & $197>169$ & 14.2 & 83.5 & 9.7 & 9.9 & 77.7 & 6.1 & 8.4 & 80.4 & 6.6 & 6.8 \\
\hline 51 & Chlorpyrifos methyl & $286>93$ & 13.3 & 76.8 & 15.4 & 21.6 & 74.2 & 9.1 & 14.9 & 80.6 & 5.5 & 5.5 \\
\hline 52 & Chlorthal dimethyl & $301>223$ & 14.3 & 85.2 & 8.0 & 9.7 & 74.4 & 7.3 & 10.4 & 81.6 & 4.6 & 8.2 \\
\hline 53 & Chlorthiophos & $360>269$ & 17.0 & 84.2 & 6.3 & 13.0 & 76.7 & 8.2 & 9.6 & 78.1 & 7.4 & 7.4 \\
\hline 54 & Cinidon ethyl & $393>330$ & 24.6 & 84.3 & 2.3 & 5.1 & 85.6 & 3.8 & 16.5 & 75.0 & 3.5 & 3.9 \\
\hline 55 & cis-Chlordane & $373>266$ & 15.5 & 86.2 & 7.0 & 10.0 & 80.0 & 8.9 & 13.8 & 80.2 & 3.9 & 9.0 \\
\hline 56 & cis-Nonachlor & $407>300$ & 15.8 & 79.6 & 12.3 & 23.1 & 76.6 & 25.8 & 35.1 & 77.9 & 11.9 & 14.2 \\
\hline 57 & Clodinafop propargyl & $349>266$ & 17.6 & 93.6 & 6.8 & 9.1 & 87.8 & 5.8 & 7.3 & 76.4 & 4.4 & 6.1 \\
\hline 58 & Clomazon & $125>89$ & 12.0 & 84.2 & 8.5 & 11.1 & 83.9 & 5.2 & 8.0 & 82.0 & 3.0 & 4.3 \\
\hline 59 & Cloquintocet-1-methylhexyl ester & $192>162$ & 18.7 & 83.6 & 4.9 & 9.9 & 80.9 & 3.3 & 4.5 & 78.9 & 5.4 & 6.8 \\
\hline 60 & Coumaphos & $226>163$ & 20.5 & 85.0 & 2.2 & 10.4 & 79.2 & 3.9 & 6.8 & 79.1 & 3.2 & 5.6 \\
\hline 61 & Crimidine & $156>86$ & 9.3 & 80.1 & 7.4 & 15.1 & 83.3 & 7.5 & 11.6 & 83.3 & 5.2 & 5.7 \\
\hline 62 & Cyanofenphos & $303>141$ & 17.5 & 88.8 & 13.0 & 19.4 & 83.0 & 4.7 & 10.0 & 82.4 & 6.9 & 7.4 \\
\hline 63 & Cyanophos & $243>109$ & 12.2 & 81.6 & 7.2 & 12.6 & 82.4 & 5.5 & 9.0 & 78.5 & 6.7 & 9.7 \\
\hline 64 & Cyfluthrin & $163>91$ & 21.0 & 86.6 & 7.9 & 13.1 & 82.3 & 4.3 & 6.8 & 77.2 & 3.3 & 6.0 \\
\hline 65 & Cyhalofop buthyl & $256>120$ & 19.4 & 84.5 & 2.2 & 9.4 & 80.5 & 3.8 & 6.4 & 78.6 & 4.4 & 6.6 \\
\hline 66 & Cyhalothrin & $181>152$ & 19.5 & 81.1 & 2.6 & 9.4 & 80.3 & 4.3 & 9.5 & 74.2 & 6.3 & 11.4 \\
\hline 67 & Cypermethrin & $163>127$ & 21.3 & 84.6 & 2.7 & 7.1 & 79.6 & 3.0 & 5.8 & 75.1 & 3.7 & 5.8 \\
\hline 68 & Cyproconazole & $222>125$ & 16.6 & 84.3 & 6.4 & 10.5 & 82.1 & 3.4 & 8.4 & 81.2 & 3.2 & 6.2 \\
\hline 69 & Deltamethrin & $253>174$ & 23.1 & 93.7 & 4.2 & 9.2 & 73.0 & 4.4 & 5.7 & 71.1 & 4.4 & 5.5 \\
\hline
\end{tabular}


FASRAC and official method

\begin{tabular}{|c|c|c|c|c|c|c|c|c|c|c|c|c|c|c|}
\hline \multicolumn{3}{|c|}{ FASRAC } & \multicolumn{12}{|c|}{ Official method } \\
\hline \multicolumn{3}{|c|}{ Apple } & \multicolumn{3}{|c|}{ Wheat flour } & \multicolumn{3}{|c|}{ Soy beans } & \multicolumn{3}{|c|}{ Spinach } & & Apple & \\
\hline $\begin{array}{c}\text { Recovery } \\
(\%)\end{array}$ & $\begin{array}{c}\mathrm{RSD}_{1}{ }^{*} \\
(\%)\end{array}$ & $\begin{array}{c}\operatorname{RSD}_{2}{ }^{* *} \\
(\%)\end{array}$ & $\begin{array}{l}\text { Recovery } \\
(\%)\end{array}$ & $\begin{array}{c}\mathrm{RSD}_{1}{ }^{*} \\
(\%)\end{array}$ & $\begin{array}{c}\mathrm{RSD}_{2}{ }^{* *} \\
(\%)\end{array}$ & $\begin{array}{l}\text { Recovery } \\
(\%)\end{array}$ & $\begin{array}{c}\mathrm{RSD}_{1}{ }^{*} \\
(\%)\end{array}$ & $\begin{array}{c}\mathrm{RSD}_{2}{ }^{* *} \\
(\%)\end{array}$ & $\begin{array}{l}\text { Recovery } \\
(\%)\end{array}$ & $\begin{array}{c}\mathrm{RSD}_{1}{ }^{*} \\
(\%)\end{array}$ & $\begin{array}{c}\mathrm{RSD}_{2}{ }^{* *} \\
(\%)\end{array}$ & $\begin{array}{c}\text { Recovery } \\
(\%)\end{array}$ & $\begin{array}{c}\mathrm{RSD}_{1}{ }^{*} \\
(\%)\end{array}$ & $\begin{array}{c}\mathrm{RSD}_{2}{ }^{* *} \\
(\%)\end{array}$ \\
\hline 82.0 & 4.4 & 4.5 & 85.0 & 2.5 & 12.2 & 86.5 & 3.3 & 8.6 & 85.4 & 2.3 & 7.0 & 86.6 & 3.3 & 7.3 \\
\hline 81.3 & 5.3 & 6.8 & 84.1 & 3.2 & 13.0 & 85.3 & 2.3 & 10.3 & 84.7 & 6.2 & 6.7 & 89.7 & 3.1 & 5.3 \\
\hline 87.4 & 5.0 & 6.8 & 75.6 & 3.4 & 32.3 & 53.6 & 8.2 & 34.1 & 86.6 & 2.2 & 11.9 & 91.5 & 4.3 & 9.5 \\
\hline 84.2 & 4.3 & 5.4 & 75.7 & 3.7 & 17.5 & 65.3 & 2.7 & 15.2 & 84.2 & 4.6 & 7.3 & 80.9 & 2.5 & 17.5 \\
\hline 52.1 & 4.5 & 13.2 & 59.5 & 7.3 & 29.4 & 63.8 & 5.4 & 29.7 & 42.6 & 6.2 & 20.5 & 50.6 & 6.2 & 21.3 \\
\hline 82.4 & 9.2 & 9.2 & 86.1 & 6.0 & 11.8 & 81.9 & 5.4 & 9.5 & 88.7 & 4.6 & 7.2 & 91.0 & 2.5 & 8.9 \\
\hline 78.2 & 4.1 & 4.8 & 77.3 & 3.3 & 24.1 & 86.3 & 3.3 & 10.0 & 74.3 & 5.4 & 5.4 & 87.5 & 5.1 & 7.6 \\
\hline 83.6 & 6.1 & 6.1 & 80.6 & 4.9 & 15.1 & 82.8 & 5.2 & 9.3 & 87.6 & 5.3 & 6.6 & 91.1 & 3.6 & 8.0 \\
\hline 82.6 & 8.2 & 10.1 & 70.0 & 13.4 & 31.6 & 56.5 & 13.6 & 23.9 & 85.5 & 6.8 & 8.1 & 89.9 & 5.3 & 8.4 \\
\hline 81.8 & 6.0 & 7.0 & 86.4 & 10.7 & 10.7 & 89.5 & 4.8 & 11.2 & 88.0 & 6.5 & 9.5 & 95.0 & 5.0 & 13.9 \\
\hline 68.6 & 5.8 & 5.8 & 60.9 & 2.3 & 27.1 & 67.7 & 5.0 & 18.0 & 71.5 & 6.2 & 9.1 & 66.8 & 5.0 & 15.5 \\
\hline 83.3 & 7.3 & 8.0 & 85.1 & 4.7 & 10.1 & 85.2 & 5.9 & 8.2 & 86.9 & 6.3 & 6.3 & 92.1 & 5.0 & 5.1 \\
\hline 81.9 & 4.8 & 4.9 & 79.9 & 2.5 & 11.4 & 77.2 & 5.5 & 6.6 & 84.3 & 5.0 & 11.4 & 86.5 & 3.4 & 7.0 \\
\hline 84.7 & 4.5 & 10.9 & 89.1 & 3.2 & 9.9 & 83.6 & 9.3 & 12.9 & 86.4 & 6.4 & 12.8 & 90.5 & 3.9 & 9.0 \\
\hline 84.2 & 2.6 & 4.9 & 83.7 & 2.4 & 9.1 & 80.9 & 3.6 & 7.7 & 85.1 & 1.7 & 4.0 & 89.2 & 3.3 & 4.4 \\
\hline 82.2 & 2.6 & 4.4 & 85.8 & 2.8 & 8.1 & 80.9 & 3.7 & 8.7 & 81.5 & 2.8 & 5.8 & 87.5 & 3.0 & 4.4 \\
\hline 85.0 & 4.1 & 9.8 & 83.5 & 4.9 & 14.3 & 79.4 & 6.1 & 12.9 & 85.0 & 3.7 & 5.0 & 91.1 & 5.5 & 5.5 \\
\hline 77.3 & 2.7 & 4.3 & 85.2 & 3.2 & 12.3 & 78.9 & 2.5 & 9.4 & 80.9 & 4.8 & 5.9 & 84.9 & 4.0 & 7.0 \\
\hline 82.1 & 7.3 & 8.8 & 87.1 & 9.6 & 19.4 & 83.7 & 7.0 & 17.1 & 87.9 & 5.5 & 6.9 & 93.7 & 7.5 & 7.5 \\
\hline 82.5 & 6.5 & 8.4 & 86.1 & 6.1 & 14.8 & 85.3 & 7.1 & 11.0 & 86.0 & 4.5 & 9.1 & 85.5 & 4.0 & 5.2 \\
\hline 79.6 & 6.0 & 6.7 & 88.8 & 5.8 & 8.6 & 84.5 & 7.3 & 11.5 & 74.0 & 4.4 & 9.2 & 82.3 & 4.7 & 8.2 \\
\hline 82.5 & 3.2 & 5.0 & 77.4 & 1.7 & 15.7 & 62.9 & 9.2 & 14.6 & 82.0 & 2.3 & 3.0 & 88.3 & 2.0 & 2.8 \\
\hline 82.7 & 3.5 & 3.7 & 76.6 & 1.7 & 15.7 & 79.4 & 2.6 & 7.7 & 81.6 & 2.0 & 6.0 & 89.4 & 2.7 & 3.9 \\
\hline 82.4 & 5.9 & 6.0 & 82.7 & 4.7 & 10.7 & 83.4 & 4.8 & 11.5 & 85.1 & 3.2 & 7.6 & 87.9 & 3.6 & 6.3 \\
\hline 82.7 & 4.5 & 9.6 & 82.8 & 7.8 & 18.5 & 81.6 & 9.7 & 10.8 & 86.7 & 4.1 & 8.4 & 92.0 & 6.5 & 6.5 \\
\hline 82.9 & 6.9 & 6.9 & 84.0 & 5.3 & 13.1 & 79.6 & 4.1 & 5.9 & 82.3 & 3.9 & 6.1 & 88.1 & 4.7 & 6.6 \\
\hline 82.1 & 3.3 & 6.2 & 76.9 & 4.0 & 15.6 & 75.7 & 6.0 & 12.3 & 85.9 & 4.1 & 9.4 & 86.8 & 3.8 & 4.5 \\
\hline 81.4 & 3.6 & 10.5 & 86.2 & 8.1 & 9.9 & 62.9 & 3.8 & 22.4 & 85.0 & 3.4 & 4.1 & 90.6 & 4.6 & 5.4 \\
\hline 82.7 & 5.1 & 7.8 & 81.2 & 7.4 & 12.8 & 75.0 & 4.5 & 5.4 & 84.2 & 3.8 & 4.6 & 89.1 & 3.0 & 4.2 \\
\hline 84.6 & 11.0 & 11.0 & 81.3 & 12.0 & 16.7 & 77.9 & 6.9 & 10.2 & 82.7 & 5.9 & 9.2 & 93.5 & 4.5 & 9.1 \\
\hline 81.8 & 4.5 & 4.6 & 83.9 & 7.3 & 8.8 & 81.6 & 3.8 & 7.1 & 82.9 & 3.8 & 5.0 & 89.5 & 3.3 & 6.0 \\
\hline 77.7 & 5.9 & 9.4 & 84.7 & 5.8 & 7.5 & 76.0 & 7.7 & 7.7 & 79.7 & 2.4 & 5.9 & 80.3 & 4.1 & 7.7 \\
\hline 66.4 & 4.5 & 4.9 & 64.4 & 4.0 & 30.2 & 60.0 & 3.4 & 17.2 & 73.2 & 4.8 & 10.0 & 64.9 & 8.4 & 15.3 \\
\hline 81.2 & 2.3 & 6.0 & 86.1 & 3.0 & 14.3 & 83.4 & 3.7 & 11.0 & 85.5 & 3.6 & 6.1 & 88.9 & 3.3 & 6.9 \\
\hline 93.2 & 14.1 & 17.2 & 107.0 & 4.6 & 20.8 & 101.4 & 12.3 & 13.3 & 101.0 & 3.6 & 14.1 & 92.3 & 6.6 & 16.9 \\
\hline 79.4 & 5.1 & 8.3 & 78.3 & 8.6 & 15.4 & 74.6 & 7.4 & 11.2 & 81.9 & 5.0 & 7.8 & 87.8 & 7.9 & 9.6 \\
\hline 58.3 & 21.5 & 27.8 & 51.9 & 9.2 & 15.7 & 59.7 & 14.9 & 20.9 & 70.5 & 8.3 & 15.5 & 81.2 & 11.0 & 27.2 \\
\hline 84.7 & 4.0 & 4.4 & 81.6 & 3.6 & 10.5 & 76.5 & 6.1 & 12.5 & 84.3 & 2.0 & 5.4 & 88.2 & 4.6 & 4.6 \\
\hline 83.6 & 8.5 & 8.5 & 71.5 & 6.3 & 17.2 & 47.8 & 9.6 & 28.7 & 66.4 & 8.1 & 16.9 & 86.5 & 5.5 & 5.7 \\
\hline 86.2 & 8.6 & 11.5 & 84.9 & 9.5 & 12.4 & 83.5 & 7.7 & 9.9 & 84.6 & 4.4 & 12.2 & 89.3 & 9.6 & 9.6 \\
\hline 86.5 & 2.0 & 5.3 & 80.5 & 5.3 & 20.2 & 83.6 & 28.7 & 33.3 & 83.2 & 5.3 & 10.0 & 90.4 & 4.4 & 10.9 \\
\hline 77.0 & 4.0 & 4.4 & 79.6 & 3.8 & 18.2 & 74.5 & 3.6 & 8.3 & 81.5 & 4.2 & 9.8 & 83.5 & 3.0 & 7.0 \\
\hline 84.7 & 9.2 & 9.7 & 84.1 & 21.8 & 26.3 & 88.2 & 7.9 & 25.2 & 90.5 & 12.7 & 13.8 & 96.2 & 18.4 & 22.2 \\
\hline 86.8 & 12.3 & 14.5 & 87.7 & 9.5 & 11.5 & 79.8 & 12.8 & 12.8 & 86.2 & 13.0 & 13.0 & 88.5 & 6.8 & 9.3 \\
\hline 67.9 & 3.3 & 5.5 & 63.0 & 2.6 & 31.4 & 66.2 & 9.7 & 20.4 & 75.0 & 8.7 & 9.0 & 65.3 & 11.4 & 17.2 \\
\hline 84.4 & 9.3 & 10.3 & 87.9 & 9.4 & 14.1 & 75.3 & 9.8 & 12.4 & 82.2 & 1.9 & 7.7 & 87.0 & 8.7 & 8.7 \\
\hline 83.4 & 3.4 & 5.3 & 80.5 & 2.0 & 12.5 & 87.0 & 3.6 & 22.5 & 86.4 & 1.3 & 5.5 & 89.2 & 1.9 & 3.6 \\
\hline 76.0 & 4.2 & 6.4 & 74.1 & 1.5 & 18.5 & 75.7 & 5.6 & 8.9 & 83.7 & 5.7 & 7.9 & 65.2 & 3.7 & 18.0 \\
\hline 82.7 & 5.5 & 7.1 & 86.9 & 5.2 & 16.3 & 84.3 & 6.8 & 12.9 & 89.7 & 6.2 & 11.2 & 90.6 & 4.8 & 9.1 \\
\hline 89.5 & 4.7 & 8.0 & 83.7 & 6.6 & 19.5 & 78.8 & 5.2 & 12.4 & 89.3 & 4.6 & 9.8 & 94.6 & 3.9 & 13.4 \\
\hline 84.0 & 5.0 & 9.1 & 80.0 & 9.1 & 17.3 & 79.2 & 6.9 & 7.7 & 85.1 & 4.1 & 10.3 & 91.6 & 6.2 & 8.0 \\
\hline 83.9 & 6.3 & 6.3 & 83.8 & 5.5 & 14.8 & 78.2 & 10.8 & 18.9 & 88.3 & 3.3 & 6.2 & 87.8 & 4.8 & 7.1 \\
\hline 82.2 & 4.9 & 7.5 & 79.9 & 4.6 & 8.9 & 67.0 & 9.4 & 17.9 & 84.4 & 3.6 & 7.3 & 89.7 & 5.1 & 7.9 \\
\hline 80.9 & 2.7 & 4.2 & 85.5 & 2.9 & 10.6 & 77.0 & 4.0 & 10.0 & 79.6 & 4.5 & 5.8 & 85.1 & 6.0 & 10.5 \\
\hline 84.2 & 8.0 & 8.0 & 79.0 & 5.8 & 22.3 & 62.6 & 11.9 & 17.9 & 83.5 & 5.6 & 6.5 & 90.2 & 4.7 & 5.6 \\
\hline 84.8 & 8.0 & 11.1 & 80.2 & 10.6 & 24.7 & 60.3 & 16.0 & 21.8 & 84.0 & 6.3 & 7.8 & 89.4 & 6.3 & 9.1 \\
\hline 79.4 & 3.8 & 6.2 & 84.2 & 7.7 & 12.1 & 79.1 & 5.1 & 9.3 & 78.7 & 4.1 & 6.4 & 86.4 & 3.0 & 5.2 \\
\hline 82.9 & 4.0 & 5.0 & 85.8 & 3.6 & 7.6 & 84.3 & 4.0 & 8.4 & 86.6 & 2.7 & 8.2 & 88.1 & 2.9 & 5.5 \\
\hline 83.4 & 3.7 & 4.7 & 83.8 & 3.8 & 9.9 & 79.5 & 4.0 & 8.5 & 84.4 & 2.9 & 9.3 & 87.4 & 4.0 & 4.3 \\
\hline 82.4 & 2.9 & 5.4 & 83.6 & 2.3 & 9.5 & 81.3 & 4.0 & 10.1 & 83.6 & 4.5 & 6.3 & 89.9 & 3.5 & 5.0 \\
\hline 79.9 & 4.9 & 6.7 & 82.5 & 4.7 & 14.9 & 81.0 & 5.6 & 13.4 & 84.0 & 4.6 & 7.4 & 86.9 & 6.5 & 7.6 \\
\hline 86.6 & 6.4 & 7.3 & 81.4 & 9.9 & 10.8 & 86.4 & 13.0 & 13.0 & 85.7 & 5.7 & 10.1 & 92.8 & 6.0 & 12.2 \\
\hline 84.3 & 4.7 & 5.2 & 88.3 & 4.3 & 13.5 & 85.3 & 5.5 & 15.6 & 88.5 & 5.2 & 10.3 & 92.3 & 5.1 & 10.6 \\
\hline 91.2 & 4.2 & 5.9 & 90.5 & 2.3 & 13.5 & 81.3 & 3.5 & 9.0 & 84.1 & 4.9 & 8.6 & 94.8 & 7.2 & 7.3 \\
\hline 83.8 & 3.4 & 5.7 & 84.7 & 1.6 & 13.5 & 81.4 & 3.3 & 9.1 & 84.3 & 2.7 & 6.7 & 90.8 & 2.6 & 5.3 \\
\hline 90.3 & 4.9 & 6.0 & 82.6 & 2.8 & 17.2 & 80.8 & 3.6 & 7.1 & 83.0 & 4.7 & 11.1 & 112.4 & 5.4 & 10.1 \\
\hline 83.1 & 2.7 & 5.4 & 84.3 & 1.6 & 12.2 & 77.1 & 3.7 & 7.5 & 84.2 & 3.3 & 6.8 & 91.4 & 3.5 & 4.9 \\
\hline 83.8 & 4.0 & 6.3 & 83.2 & 5.9 & 9.1 & 80.2 & 4.7 & 10.5 & 86.8 & 3.2 & 5.0 & 89.5 & 2.4 & 5.3 \\
\hline 83.8 & 4.4 & 6.0 & 85.7 & 2.7 & 14.3 & 78.3 & 3.7 & 9.0 & 77.9 & 5.2 & 8.2 & 98.5 & 3.4 & 4.6 \\
\hline
\end{tabular}


Table 1

\begin{tabular}{|c|c|c|c|c|c|c|c|c|c|c|c|c|}
\hline \multirow{3}{*}{ No. } & \multirow{3}{*}{ Pesticides } & \multirow{3}{*}{$\begin{array}{c}\text { MRM } \\
\text { transitions } \\
\quad(\mathrm{m} / \mathrm{z})\end{array}$} & \multirow{3}{*}{$\begin{array}{c}\mathrm{RT} \\
(\mathrm{min})\end{array}$} & \multicolumn{9}{|c|}{ FASRAC } \\
\hline & & & & \multicolumn{3}{|c|}{ Wheat flour } & \multicolumn{3}{|c|}{ Soy beans } & & Spinach & \\
\hline & & & & $\begin{array}{c}\text { Recovery } \\
(\%)\end{array}$ & $\begin{array}{c}\mathrm{RSD}_{1}^{*} \\
(\%)\end{array}$ & $\begin{array}{c}\mathrm{RSD}_{2}{ }^{* * *} \\
(\%)\end{array}$ & $\begin{array}{c}\text { Recovery } \\
(\%)\end{array}$ & $\begin{array}{c}\mathrm{RSD}_{1}^{*} \\
(\%)\end{array}$ & $\begin{array}{c}\mathrm{RSD}_{2}^{* *} \\
(\%)\end{array}$ & $\begin{array}{c}\text { Recovery } \\
(\%)\end{array}$ & $\begin{array}{c}\mathrm{RSD}_{1}^{*} \\
(\%)\end{array}$ & $\begin{array}{c}\mathrm{RSD}_{2}{ }^{* *} \\
(\%)\end{array}$ \\
\hline 70 & Dialifos & $208>181$ & 19.9 & 82.8 & 6.4 & 7.4 & 77.9 & 4.4 & 7.2 & 78.1 & 4.1 & 5.7 \\
\hline 71 & Di Allate & $234>150$ & 11.3 & 80.7 & 7.3 & 12.7 & 72.5 & 3.9 & 9.8 & 79.1 & 4.4 & 6.0 \\
\hline 72 & Diazinon & $304>179$ & 12.3 & 81.4 & 13.5 & 15.7 & 80.9 & 7.3 & 9.7 & 81.3 & 6.2 & 8.9 \\
\hline 73 & Diazinon oxon & $273>137$ & 12.0 & 83.2 & 6.9 & 9.8 & 73.2 & 6.7 & 9.6 & 78.8 & 5.9 & 5.9 \\
\hline 74 & Dichlobenil & $171>100$ & 7.5 & 64.0 & 3.1 & 13.8 & 60.3 & 3.9 & 18.5 & 68.1 & 4.7 & 8.8 \\
\hline 75 & Dichlofenthion & $279>223$ & 13.1 & 80.9 & 5.3 & 8.5 & 77.6 & 3.7 & 5.8 & 79.9 & 3.0 & 4.7 \\
\hline 76 & Dichloran & $206>176$ & 11.7 & 85.9 & 5.4 & 5.4 & 84.8 & 3.4 & 7.1 & 79.4 & 4.3 & 5.0 \\
\hline 77 & Dichlorvos & $185>93$ & 6.5 & 61.9 & 7.1 & 7.8 & 48.9 & 4.9 & 17.5 & 60.8 & 6.4 & 15.9 \\
\hline 78 & Diclocymet & $221>155$ & 15.2 & 98.0 & 7.1 & 14.4 & 81.9 & 6.5 & 17.0 & 85.0 & 6.8 & 10.6 \\
\hline 79 & Dicofol & $139>111$ & 14.5 & 82.2 & 2.9 & 10.8 & 77.5 & 3.2 & 8.3 & 80.8 & 4.4 & 6.5 \\
\hline 80 & Dicrotophos & $193>127$ & 11.0 & 80.9 & 5.8 & 11.9 & 83.5 & 8.3 & 11.9 & 72.8 & 5.5 & 6.3 \\
\hline 81 & Dieldrin & $277>241$ & 16.3 & 70.9 & 25.5 & 29.8 & 74.0 & 10.0 & 20.3 & 77.9 & 15.1 & 22.0 \\
\hline 82 & Diethofencarb & $225>125$ & 14.2 & 84.9 & 8.5 & 10.4 & 84.4 & 7.6 & 9.3 & 82.3 & 6.5 & 9.0 \\
\hline 83 & Difenoconazole & $323>265$ & 22.7 & 84.9 & 2.7 & 6.6 & 84.1 & 2.1 & 3.4 & 78.2 & 3.6 & 5.2 \\
\hline 84 & Difenzoquat & $234>102$ & 16.2 & 86.6 & 6.1 & 10.1 & 71.1 & 5.9 & 8.0 & 81.9 & 7.9 & 8.8 \\
\hline 85 & Diflufenican & $394>266$ & 17.9 & 83.5 & 3.0 & 9.1 & 78.0 & 5.0 & 8.3 & 82.0 & 4.5 & 6.3 \\
\hline 86 & Diflumetorim & $298>127$ & 15.6 & 80.6 & 2.8 & 13.0 & 79.5 & 4.4 & 12.5 & 86.0 & 3.0 & 6.4 \\
\hline 87 & Dimepiperate & $145>112$ & 15.3 & 79.0 & 10.2 & 15.5 & 78.1 & 6.7 & 7.0 & 82.8 & 4.6 & 5.0 \\
\hline 88 & Dimethametryn & $212>122$ & 15.0 & 88.1 & 7.9 & 10.2 & 76.1 & 7.0 & 8.4 & 83.4 & 7.8 & 7.8 \\
\hline 89 & Dimethipin & $124>76$ & 11.9 & 83.1 & 20.1 & 31.9 & 91.1 & 10.5 & 27.8 & 81.1 & 10.9 & 14.9 \\
\hline 90 & Dimethoate & $229>87$ & 11.7 & 101.9 & 4.2 & 14.8 & 106.0 & 8.8 & 14.2 & 102.8 & 7.2 & 7.5 \\
\hline 91 & Diniconazol & $268>232$ & 16.9 & 79.8 & 6.2 & 14.7 & 81.1 & 3.9 & 7.2 & 78.8 & 4.3 & 4.3 \\
\hline 92 & Diofenolan & $300>186$ & 17.5 & 90.1 & 11.5 & 16.5 & 82.2 & 10.1 & 12.4 & 87.4 & 7.2 & 12.4 \\
\hline 93 & Dioxathion & $270>141$ & 12.1 & 80.1 & 19.5 & 23.0 & 72.6 & 13.3 & 26.9 & 79.8 & 11.3 & 14.0 \\
\hline 94 & Diphenamid & $239>167$ & 14.6 & 81.6 & 8.8 & 15.9 & 85.2 & 7.4 & 10.9 & 86.5 & 9.0 & 9.0 \\
\hline 95 & Diphenyl & $154>153$ & 8.0 & 57.6 & 4.4 & 16.1 & 51.2 & 5.8 & 25.0 & 59.8 & 4.6 & 8.7 \\
\hline 96 & Diphenylamine & $169>168$ & 10.6 & 77.7 & 3.5 & 9.0 & 43.8 & 3.0 & 20.4 & 75.1 & 3.6 & 4.7 \\
\hline 97 & Disulfoton sulfone & $213>97$ & 15.6 & 88.3 & 5.5 & 10.5 & 86.5 & 7.3 & 9.1 & 80.4 & 5.3 & 7.8 \\
\hline 98 & Dithiopyr & $354>306$ & 13.6 & 83.3 & 7.6 & 11.2 & 80.2 & 5.6 & 5.9 & 80.2 & 6.9 & 6.9 \\
\hline 99 & Echlomezol & $211>183$ & 8.7 & 75.2 & 3.8 & 12.5 & 71.2 & 3.4 & 12.1 & 68.2 & 6.2 & 8.0 \\
\hline 100 & $E$-Chlorfenvinphos & $323>267$ & 14.8 & 85.1 & 6.1 & 11.3 & 74.7 & 7.8 & 9.0 & 83.3 & 4.7 & 5.5 \\
\hline 101 & $E$-Dimethylvinphos & $295>109$ & 14.0 & 83.4 & 2.2 & 3.7 & 81.6 & 3.6 & 5.5 & 81.2 & 3.4 & 5.7 \\
\hline 102 & $E$-Metominostrobin & $191>160$ & 15.9 & 84.2 & 3.9 & 8.1 & 81.0 & 6.0 & 10.1 & 83.5 & 5.8 & 7.4 \\
\hline 103 & Endrin & $263>193$ & 16.7 & 84.4 & 11.9 & 18.2 & 81.9 & 7.0 & 11.7 & 80.2 & 7.7 & 10.5 \\
\hline 104 & EPN & $157>110$ & 17.5 & 90.6 & 9.4 & 14.9 & 81.8 & 9.0 & 10.8 & 84.4 & 9.0 & 9.2 \\
\hline 105 & EPTC & $189>86$ & 7.7 & 66.3 & 8.3 & 18.5 & 62.4 & 4.3 & 23.7 & 63.3 & 7.1 & 9.9 \\
\hline 106 & E-Pyrifenox & $262>192$ & 15.5 & 74.8 & 12.4 & 21.1 & 76.7 & 11.4 & 17.4 & 74.5 & 6.9 & 6.9 \\
\hline 107 & E-Pyriminobac methyl & $302>256$ & 17.6 & 84.9 & 2.6 & 9.5 & 81.1 & 4.7 & 7.8 & 85.9 & 5.0 & 13.5 \\
\hline 108 & Esfenvalerate & $167>125$ & 22.4 & 89.2 & 2.6 & 6.5 & 80.1 & 1.8 & 4.3 & 74.8 & 3.7 & 4.2 \\
\hline 109 & Esprocarb & $222>91$ & 14.1 & 80.5 & 5.1 & 10.7 & 78.1 & 5.3 & 5.3 & 82.3 & 5.1 & 6.1 \\
\hline 110 & Ethalfluralin & $316>276$ & 10.8 & 90.2 & 5.4 & 12.9 & 87.2 & 4.1 & 8.9 & 75.9 & 6.1 & 7.4 \\
\hline 111 & Ethion & $384>231$ & 16.9 & 82.0 & 6.0 & 10.5 & 85.2 & 8.9 & 9.5 & 79.2 & 8.5 & 8.5 \\
\hline 112 & Ethofumesate & $207>161$ & 13.9 & 81.9 & 3.2 & 12.0 & 79.0 & 5.3 & 11.5 & 83.6 & 6.3 & 8.7 \\
\hline 113 & Ethoprophos & $200>158$ & 10.7 & 86.4 & 2.5 & 10.6 & 84.4 & 3.5 & 4.7 & 81.0 & 5.8 & 5.8 \\
\hline 114 & Etofenprox & $163>107$ & 21.5 & 84.4 & 3.1 & 6.4 & 75.3 & 2.3 & 4.0 & 76.9 & 3.5 & 5.3 \\
\hline 115 & Etoxazole & $300>270$ & 18.7 & 83.0 & 6.1 & 15.0 & 73.3 & 5.1 & 8.4 & 80.7 & 8.2 & 9.9 \\
\hline 116 & Etoxazole metabolite & $333>276$ & 18.8 & 84.5 & 5.1 & 13.8 & 81.9 & 6.8 & 7.8 & 82.0 & 4.0 & 5.3 \\
\hline 117 & Etrimfos & $292>181$ & 12.6 & 86.5 & 7.4 & 12.5 & 80.6 & 8.7 & 8.7 & 81.5 & 5.4 & 7.4 \\
\hline 118 & Famphur & $218>109$ & 17.4 & 81.3 & 3.2 & 10.1 & 81.5 & 8.3 & 9.0 & 84.5 & 3.7 & 7.6 \\
\hline 119 & Fenamiphos & $154>139$ & 15.8 & 84.7 & 9.4 & 28.4 & 75.5 & 9.9 & 19.8 & 61.9 & 12.1 & 16.5 \\
\hline 120 & Fenarimol & $219>107$ & 19.7 & 89.5 & 3.7 & 10.8 & 86.3 & 2.2 & 6.6 & 86.5 & 5.4 & 6.5 \\
\hline 121 & Fenchlorphos & $285>270$ & 13.6 & 84.3 & 6.2 & 7.6 & 76.7 & 2.7 & 10.6 & 80.8 & 4.4 & 4.8 \\
\hline 122 & Fenitrothion & $277>260$ & 13.9 & 82.7 & 6.9 & 9.1 & 79.8 & 8.4 & 11.2 & 77.2 & 3.4 & 8.2 \\
\hline 123 & Fenoxanil & $293>155$ & 16.6 & 86.6 & 8.7 & 10.7 & 82.8 & 3.4 & 18.5 & 81.6 & 4.8 & 6.9 \\
\hline 124 & Fenpropathrin & $181>152$ & 18.7 & 88.3 & 3.1 & 11.8 & 76.7 & 6.6 & 14.0 & 79.1 & 3.7 & 7.2 \\
\hline 125 & Fenpropimorph & $128>110$ & 14.3 & 78.7 & 6.4 & 8.5 & 70.7 & 4.4 & 9.2 & 78.3 & 4.9 & 5.5 \\
\hline 126 & Fensulfothion & $293>97$ & 16.8 & 90.7 & 6.0 & 11.3 & 91.8 & 4.2 & 7.1 & 78.7 & 2.8 & 4.1 \\
\hline 127 & Fenthion & $278>109$ & 14.3 & 79.2 & 9.8 & 9.8 & 73.2 & 4.7 & 13.5 & 69.1 & 9.2 & 9.2 \\
\hline 128 & Fenvalerate & $167>125$ & 22.4 & 87.6 & 2.5 & 7.1 & 79.4 & 1.2 & 2.6 & 75.9 & 3.5 & 4.4 \\
\hline 129 & Fipronil & $367>215$ & 15.0 & 79.0 & 20.0 & 20.0 & 76.9 & 9.7 & 23.9 & 85.1 & 15.2 & 15.2 \\
\hline 130 & Flamprop methyl & $276>105$ & 16.2 & 85.4 & 8.9 & 10.7 & 78.8 & 9.7 & 14.4 & 85.7 & 8.5 & 8.5 \\
\hline 131 & Fluacrypyrim & $189>129$ & 17.0 & 83.2 & 6.3 & 9.2 & 81.2 & 7.3 & 9.2 & 81.9 & 2.5 & 4.4 \\
\hline 132 & Fluazifop buthyl & $383>282$ & 16.6 & 83.2 & 8.3 & 12.7 & 80.1 & 6.3 & 12.1 & 80.7 & 4.3 & 6.0 \\
\hline 133 & Flucythrinate & $199>157$ & 21.4 & 87.7 & 2.9 & 6.6 & 83.7 & 2.5 & 4.8 & 74.2 & 3.0 & 4.2 \\
\hline 134 & Fludioxonil & $248>127$ & 16.0 & 82.9 & 6.4 & 8.6 & 77.8 & 6.9 & 7.9 & 83.8 & 4.2 & 7.4 \\
\hline 135 & Flufenpyr ethyl & $408>345$ & 16.7 & 86.5 & 5.0 & 10.1 & 83.5 & 6.8 & 9.7 & 78.5 & 9.5 & 9.5 \\
\hline 136 & Flumetralin & $143>107$ & 15.6 & 91.1 & 5.2 & 10.4 & 82.0 & 8.0 & 8.0 & 77.4 & 5.8 & 5.8 \\
\hline 137 & Flumiclorac pentyl & $423>318$ & 23.3 & 86.9 & 1.4 & 8.3 & 84.5 & 3.0 & 5.6 & 72.5 & 3.2 & 5.4 \\
\hline 138 & Fluquinconazole & $340>298$ & 20.5 & 87.1 & 3.0 & 10.5 & 82.4 & 2.5 & 3.8 & 81.4 & 3.5 & 6.6 \\
\hline
\end{tabular}


Continued.

\begin{tabular}{|c|c|c|c|c|c|c|c|c|c|c|c|c|c|c|}
\hline \multicolumn{3}{|c|}{ FASRAC } & \multicolumn{12}{|c|}{ Official method } \\
\hline \multicolumn{3}{|c|}{ Apple } & \multicolumn{3}{|c|}{ Wheat flour } & \multicolumn{3}{|c|}{ Soy beans } & \multicolumn{3}{|c|}{ Spinach } & & Apple & \\
\hline $\begin{array}{c}\text { Recovery } \\
(\%)\end{array}$ & $\begin{array}{c}\mathrm{RSD}_{1}^{*} \\
(\%)\end{array}$ & $\begin{array}{c}\mathrm{RSD}_{2}^{* *} \\
(\%)\end{array}$ & $\begin{array}{c}\text { Recovery } \\
(\%)\end{array}$ & $\begin{array}{c}\mathrm{RSD}_{1}^{*} \\
(\%)\end{array}$ & $\begin{array}{c}\mathrm{RSD}_{2}^{* *} \\
(\%)\end{array}$ & $\begin{array}{c}\text { Recovery } \\
(\%)\end{array}$ & $\begin{array}{c}\mathrm{RSD}_{1}{ }^{*} \\
(\%)\end{array}$ & $\begin{array}{c}\mathrm{RSD}_{2}{ }^{* *} \\
(\%)\end{array}$ & $\begin{array}{c}\text { Recovery } \\
(\%)\end{array}$ & $\begin{array}{c}\mathrm{RSD}_{1}^{*} \\
(\%)\end{array}$ & $\begin{array}{c}\mathrm{RSD}_{2}^{* *} \\
(\%)\end{array}$ & $\begin{array}{c}\text { Recovery } \\
(\%)\end{array}$ & $\begin{array}{c}\mathrm{RSD}_{1}{ }^{*} \\
(\%)\end{array}$ & $\begin{array}{c}\mathrm{RSD}_{2}{ }^{* *} \\
(\%)\end{array}$ \\
\hline 80.6 & 2.2 & 4.9 & 77.6 & 5.0 & 11.5 & 78.5 & 3.8 & 5.6 & 79.1 & 3.1 & 5.4 & 87.1 & 3.6 & 4.6 \\
\hline 80.0 & 4.6 & 6.1 & 81.3 & 2.1 & 20.2 & 78.4 & 3.4 & 10.8 & 86.4 & 4.8 & 9.9 & 87.2 & 2.1 & 9.1 \\
\hline 85.8 & 3.9 & 6.2 & 83.7 & 6.4 & 19.0 & 77.2 & 6.6 & 16.7 & 86.5 & 5.0 & 8.9 & 90.3 & 5.0 & 8.1 \\
\hline 81.8 & 6.5 & 7.6 & 79.4 & 5.0 & 14.7 & 71.7 & 4.4 & 9.3 & 88.8 & 4.1 & 9.7 & 90.2 & 5.4 & 7.9 \\
\hline 59.8 & 4.3 & 9.3 & 44.3 & 5.7 & 47.4 & 54.9 & 8.6 & 27.2 & 66.7 & 9.2 & 10.0 & 50.8 & 12.7 & 24.5 \\
\hline 83.2 & 3.3 & 4.4 & 81.4 & 3.0 & 16.9 & 76.4 & 2.8 & 7.4 & 88.2 & 3.0 & 7.9 & 89.8 & 2.4 & 6.0 \\
\hline 79.6 & 3.8 & 4.8 & 85.8 & 2.5 & 12.2 & 79.9 & 5.5 & 11.2 & 84.3 & 4.1 & 6.6 & 84.0 & 3.9 & 4.2 \\
\hline 51.5 & 6.9 & 11.5 & 43.0 & 5.3 & 19.8 & 32.7 & 6.4 & 20.4 & 56.7 & 4.6 & 16.6 & 50.4 & 2.0 & 15.1 \\
\hline 85.1 & 7.9 & 8.8 & 80.7 & 8.9 & 13.3 & 82.7 & 5.8 & 7.7 & 94.2 & 5.3 & 28.2 & 87.6 & 2.9 & 8.0 \\
\hline 82.2 & 3.6 & 5.4 & 80.7 & 2.5 & 11.6 & 75.4 & 3.1 & 5.0 & 83.1 & 2.5 & 6.5 & 85.2 & 1.5 & 6.7 \\
\hline 78.4 & 7.0 & 8.7 & 78.9 & 4.0 & 10.2 & 79.2 & 5.1 & 9.6 & 71.6 & 6.4 & 7.6 & 79.4 & 3.8 & 7.6 \\
\hline 79.4 & 17.0 & 17.0 & 79.7 & 10.1 & 19.1 & 69.5 & 20.4 & 20.4 & 86.8 & 15.2 & 15.3 & 85.6 & 11.0 & 16.9 \\
\hline 83.5 & 4.7 & 8.2 & 89.5 & 9.3 & 9.5 & 81.0 & 4.2 & 7.0 & 87.9 & 5.1 & 10.7 & 91.0 & 5.9 & 8.5 \\
\hline 82.5 & 2.9 & 4.0 & 84.8 & 1.4 & 8.9 & 84.2 & 2.1 & 6.8 & 81.9 & 4.0 & 7.4 & 90.0 & 2.5 & 4.6 \\
\hline 81.3 & 7.9 & 7.9 & 80.5 & 5.7 & 9.4 & 85.0 & 10.4 & 17.3 & 86.1 & 2.4 & 7.1 & 92.4 & 6.9 & 7.2 \\
\hline 83.9 & 3.4 & 4.8 & 81.5 & 3.4 & 15.0 & 81.3 & 5.2 & 9.2 & 84.4 & 2.4 & 4.5 & 88.3 & 3.6 & 4.8 \\
\hline 85.0 & 3.9 & 6.4 & 82.5 & 3.0 & 15.1 & 79.8 & 2.4 & 7.5 & 87.6 & 3.1 & 6.2 & 92.8 & 4.3 & 4.5 \\
\hline 81.8 & 5.4 & 7.5 & 77.7 & 6.0 & 15.4 & 78.2 & 2.4 & 10.4 & 87.0 & 2.3 & 3.8 & 87.1 & 5.1 & 5.6 \\
\hline 83.3 & 6.1 & 7.0 & 83.4 & 3.6 & 13.4 & 79.4 & 7.4 & 8.1 & 87.2 & 2.8 & 8.9 & 92.5 & 3.6 & 10.0 \\
\hline 84.7 & 13.2 & 16.9 & 76.3 & 12.5 & 18.7 & 86.7 & 7.8 & 17.7 & 82.0 & 9.8 & 13.9 & 86.5 & 6.3 & 10.3 \\
\hline 105.5 & 7.2 & 9.2 & 109.3 & 6.9 & 15.2 & 104.3 & 6.7 & 15.4 & 113.1 & 7.3 & 7.3 & 112.3 & 4.8 & 6.3 \\
\hline 82.3 & 3.4 & 4.4 & 80.5 & 5.0 & 14.1 & 80.3 & 2.7 & 7.9 & 85.5 & 2.6 & 6.6 & 88.9 & 3.5 & 5.2 \\
\hline 87.6 & 7.4 & 9.8 & 81.4 & 7.9 & 16.5 & 78.6 & 5.4 & 7.9 & 86.1 & 2.7 & 3.3 & 91.5 & 2.7 & 4.8 \\
\hline 82.5 & 15.8 & 18.0 & 82.6 & 18.2 & 25.0 & 76.9 & 23.0 & 28.9 & 89.2 & 15.2 & 15.3 & 89.1 & 11.3 & 14.8 \\
\hline 81.7 & 8.8 & 9.5 & 87.8 & 10.1 & 12.4 & 78.6 & 9.6 & 17.8 & 87.0 & 5.4 & 9.8 & 90.7 & 6.3 & 6.8 \\
\hline 58.6 & 6.5 & 12.4 & 40.9 & 7.9 & 57.6 & 41.6 & 11.7 & 40.0 & 60.5 & 7.5 & 10.5 & 50.0 & 19.7 & 35.7 \\
\hline 80.4 & 2.8 & 3.2 & 64.7 & 2.8 & 18.9 & 31.4 & 2.4 & 22.0 & 79.6 & 2.2 & 7.8 & 75.9 & 1.5 & 19.1 \\
\hline 83.5 & 3.7 & 5.8 & 82.5 & 4.2 & 11.3 & 83.0 & 7.6 & 10.0 & 85.1 & 3.8 & 6.6 & 89.9 & 2.0 & 5.5 \\
\hline 83.0 & 4.7 & 5.8 & 84.5 & 4.4 & 14.0 & 81.7 & 4.8 & 12.2 & 85.5 & 3.8 & 6.9 & 89.8 & 2.3 & 6.8 \\
\hline 66.8 & 3.1 & 4.6 & 68.0 & 1.7 & 29.6 & 66.0 & 7.0 & 17.0 & 73.6 & 7.9 & 10.4 & 66.2 & 9.4 & 13.8 \\
\hline 82.5 & 4.2 & 4.2 & 82.9 & 4.4 & 10.6 & 81.0 & 3.7 & 10.8 & 86.6 & 3.6 & 5.3 & 90.1 & 3.0 & 6.8 \\
\hline 82.3 & 3.9 & 7.4 & 81.4 & 1.2 & 12.3 & 82.1 & 3.9 & 9.8 & 85.4 & 2.6 & 6.0 & 88.4 & 3.7 & 4.8 \\
\hline 82.6 & 6.3 & 7.3 & 85.8 & 5.0 & 11.4 & 82.3 & 5.2 & 12.7 & 85.9 & 3.1 & 7.2 & 90.4 & 2.9 & 6.4 \\
\hline 80.5 & 8.8 & 10.7 & 82.5 & 6.7 & 18.1 & 70.1 & 10.1 & 17.2 & 86.7 & 9.2 & 11.8 & 91.2 & 5.6 & 6.0 \\
\hline 80.3 & 6.1 & 8.4 & 85.5 & 6.2 & 8.2 & 79.5 & 10.1 & 11.8 & 87.6 & 5.3 & 7.4 & 88.9 & 3.9 & 8.2 \\
\hline 59.1 & 8.4 & 9.5 & 49.7 & 8.8 & 41.1 & 52.5 & 11.3 & 21.8 & 62.5 & 14.6 & 14.6 & 53.5 & 10.7 & 18.6 \\
\hline 64.0 & 7.3 & 21.7 & 75.2 & 14.0 & 23.3 & 72.0 & 8.6 & 20.4 & 79.1 & 7.8 & 9.8 & 69.9 & 9.9 & 17.9 \\
\hline 84.3 & 3.6 & 6.2 & 83.7 & 2.6 & 9.0 & 81.3 & 2.1 & 9.3 & 84.1 & 1.7 & 1.9 & 90.5 & 3.3 & 3.9 \\
\hline 82.7 & 2.6 & 4.4 & 86.8 & 1.0 & 9.9 & 79.3 & 2.4 & 7.2 & 82.5 & 2.5 & 5.5 & 90.9 & 3.2 & 3.8 \\
\hline 82.4 & 3.0 & 5.0 & 80.1 & 3.2 & 14.8 & 77.9 & 3.5 & 6.6 & 88.1 & 2.8 & 7.6 & 89.7 & 2.6 & 6.3 \\
\hline 80.9 & 6.7 & 6.7 & 82.4 & 3.6 & 13.9 & 82.6 & 3.8 & 11.8 & 82.8 & 3.0 & 6.8 & 85.6 & 3.1 & 6.1 \\
\hline 80.8 & 5.8 & 7.1 & 87.3 & 3.8 & 9.0 & 82.9 & 2.0 & 7.2 & 81.7 & 5.8 & 8.4 & 87.0 & 5.4 & 6.1 \\
\hline 86.0 & 3.6 & 7.5 & 84.4 & 3.4 & 11.4 & 83.4 & 5.1 & 10.0 & 88.7 & 1.9 & 5.3 & 92.7 & 3.4 & 7.0 \\
\hline 82.1 & 2.5 & 4.4 & 89.2 & 3.7 & 14.9 & 84.5 & 3.0 & 14.1 & 88.1 & 3.3 & 7.0 & 90.3 & 5.0 & 6.3 \\
\hline 84.0 & 2.9 & 4.5 & 77.8 & 1.2 & 14.2 & 68.3 & 3.9 & 19.2 & 82.8 & 1.8 & 5.9 & 89.8 & 2.1 & 4.3 \\
\hline 81.9 & 6.2 & 6.4 & 77.8 & 2.8 & 15.5 & 69.7 & 5.2 & 13.7 & 87.0 & 4.1 & 7.9 & 87.7 & 4.0 & 6.7 \\
\hline 84.9 & 3.3 & 7.9 & 83.8 & 6.2 & 13.9 & 78.7 & 5.1 & 12.2 & 84.1 & 3.7 & 6.8 & 88.6 & 3.8 & 4.9 \\
\hline 83.1 & 4.3 & 4.3 & 85.2 & 7.9 & 23.4 & 83.3 & 11.4 & 11.4 & 86.7 & 3.6 & 7.6 & 89.3 & 6.5 & 8.7 \\
\hline 84.1 & 1.9 & 5.8 & 83.4 & 2.3 & 11.4 & 79.9 & 1.5 & 11.6 & 85.5 & 4.7 & 6.0 & 91.6 & 2.9 & 5.9 \\
\hline 79.2 & 6.4 & 10.0 & 79.1 & 7.6 & 10.7 & 65.0 & 10.3 & 18.3 & 57.6 & 10.8 & 12.5 & 85.4 & 7.3 & 10.3 \\
\hline 88.5 & 2.5 & 5.2 & 85.1 & 2.0 & 13.3 & 81.0 & 4.3 & 11.0 & 87.4 & 2.2 & 2.3 & 88.1 & 1.5 & 8.5 \\
\hline 82.8 & 3.5 & 5.5 & 81.1 & 2.7 & 13.9 & 72.7 & 4.4 & 13.8 & 87.6 & 1.9 & 6.0 & 88.3 & 4.7 & 5.9 \\
\hline 79.7 & 5.4 & 5.7 & 87.2 & 3.4 & 9.2 & 82.6 & 5.1 & 9.0 & 83.2 & 4.2 & 5.7 & 88.8 & 4.7 & 7.1 \\
\hline 84.1 & 3.2 & 5.2 & 86.1 & 2.4 & 10.8 & 84.6 & 2.5 & 11.1 & 87.4 & 2.1 & 5.3 & 89.8 & 1.6 & 6.0 \\
\hline 86.7 & 9.0 & 9.0 & 84.6 & 2.1 & 12.3 & 76.9 & 6.8 & 11.9 & 82.8 & 2.3 & 3.8 & 88.8 & 3.7 & 5.7 \\
\hline 83.1 & 1.7 & 6.6 & 74.1 & 6.2 & 16.2 & 64.6 & 5.5 & 18.8 & 84.2 & 3.6 & 5.6 & 85.9 & 5.2 & 6.0 \\
\hline 79.5 & 4.0 & 5.9 & 87.7 & 4.7 & 9.0 & 90.4 & 3.3 & 12.4 & 85.9 & 3.4 & 7.5 & 87.4 & 4.6 & 5.1 \\
\hline 79.5 & 4.6 & 5.7 & 66.1 & 6.2 & 22.0 & 57.5 & 8.4 & 27.1 & 71.4 & 6.4 & 9.2 & 88.5 & 2.7 & 9.0 \\
\hline 83.1 & 2.5 & 5.0 & 82.3 & 1.8 & 11.0 & 75.8 & 2.8 & 10.1 & 81.7 & 2.9 & 5.1 & 89.8 & 2.5 & 3.8 \\
\hline 83.8 & 12.2 & 12.2 & 91.1 & 13.2 & 20.8 & 81.9 & 4.9 & 13.3 & 86.5 & 8.4 & 12.7 & 95.7 & 10.7 & 18.6 \\
\hline 84.2 & 6.3 & 8.5 & 80.1 & 5.2 & 15.8 & 85.4 & 7.7 & 22.1 & 85.3 & 4.7 & 9.6 & 91.4 & 4.9 & 6.6 \\
\hline 84.3 & 3.6 & 4.7 & 84.5 & 2.9 & 14.1 & 79.5 & 2.2 & 11.7 & 86.3 & 4.8 & 8.1 & 91.4 & 4.1 & 7.1 \\
\hline 84.0 & 4.7 & 7.7 & 79.1 & 4.4 & 10.8 & 81.0 & 6.3 & 14.1 & 85.0 & 4.6 & 5.3 & 91.5 & 3.0 & 5.5 \\
\hline 83.1 & 2.6 & 4.7 & 85.9 & 1.6 & 10.4 & 81.2 & 1.2 & 9.8 & 82.2 & 3.5 & 6.4 & 89.7 & 3.6 & 3.9 \\
\hline 82.9 & 5.8 & 8.5 & 84.5 & 3.0 & 11.6 & 76.7 & 8.2 & 14.3 & 82.9 & 4.1 & 4.5 & 88.0 & 1.5 & 6.3 \\
\hline 81.5 & 4.5 & 5.2 & 81.0 & 5.2 & 10.1 & 79.4 & 3.9 & 12.5 & 85.1 & 1.9 & 5.2 & 88.7 & 2.7 & 5.5 \\
\hline 76.9 & 6.3 & 7.5 & 78.8 & 3.5 & 11.9 & 75.6 & 6.4 & 8.4 & 78.1 & 3.7 & 8.1 & 81.9 & 4.1 & 4.9 \\
\hline 80.5 & 2.4 & 6.2 & 82.8 & 2.9 & 6.3 & 78.7 & 2.9 & 8.9 & 77.9 & 5.1 & 5.9 & 88.0 & 3.1 & 3.6 \\
\hline 83.1 & 3.2 & 5.0 & 82.9 & 1.5 & 8.7 & 80.3 & 3.2 & 10.7 & 83.2 & 2.2 & 4.7 & 87.8 & 2.5 & 4.2 \\
\hline
\end{tabular}


Table 1

\begin{tabular}{|c|c|c|c|c|c|c|c|c|c|c|c|c|}
\hline \multirow{3}{*}{ No. } & \multirow{3}{*}{ Pesticides } & \multirow{3}{*}{$\begin{array}{c}\text { MRM } \\
\text { transitions } \\
\quad(\mathrm{m} / \mathrm{z})\end{array}$} & \multirow{3}{*}{$\begin{array}{c}\mathrm{RT} \\
(\mathrm{min})\end{array}$} & \multicolumn{9}{|c|}{ FASRAC } \\
\hline & & & & \multicolumn{3}{|c|}{ Wheat flour } & \multicolumn{3}{|c|}{ Soy beans } & & Spinach & \\
\hline & & & & $\begin{array}{c}\text { Recovery } \\
(\%)\end{array}$ & $\begin{array}{c}\mathrm{RSD}_{1}^{*} \\
(\%)\end{array}$ & $\begin{array}{c}\mathrm{RSD}_{2}{ }^{* * *} \\
(\%)\end{array}$ & $\begin{array}{c}\text { Recovery } \\
(\%)\end{array}$ & $\begin{array}{c}\mathrm{RSD}_{1}^{*} \\
(\%)\end{array}$ & $\begin{array}{c}\mathrm{RSD}_{2}^{* *} \\
(\%)\end{array}$ & $\begin{array}{c}\text { Recovery } \\
(\%)\end{array}$ & $\begin{array}{c}\mathrm{RSD}_{1}{ }^{*} \\
(\%)\end{array}$ & $\begin{array}{c}\mathrm{RSD}_{2}{ }^{* *} \\
(\%)\end{array}$ \\
\hline 139 & Flurprimidol & $269>107$ & 13.2 & 85.2 & 4.3 & 7.5 & 79.4 & 3.3 & 7.9 & 80.8 & 5.7 & 5.7 \\
\hline 140 & Flusilazole & $233>165$ & 16.3 & 86.8 & 5.8 & 12.9 & 81.2 & 8.1 & 8.2 & 80.9 & 5.8 & 6.8 \\
\hline 141 & Flusilazole metabolite & $250>235$ & 11.0 & 60.2 & 11.4 & 40.2 & 75.7 & 10.2 & 10.2 & 70.8 & 2.9 & 6.6 \\
\hline 142 & Flutolanil & $281>173$ & 15.9 & 84.9 & 3.9 & 9.7 & 79.8 & 3.2 & 9.6 & 82.1 & 6.4 & 7.4 \\
\hline 143 & Fluvalinate & $250>55$ & 22.3 & 91.4 & 3.2 & 6.2 & 82.1 & 1.7 & 6.2 & 72.1 & 3.4 & 4.2 \\
\hline 144 & Fonofos & $137>109$ & 12.3 & 79.8 & 5.4 & 18.1 & 73.7 & 8.7 & 8.7 & 84.2 & 6.7 & 11.0 \\
\hline 145 & Formothion & $126>93$ & 12.9 & 55.4 & 13.3 & 13.3 & 48.5 & 12.2 & 20.8 & 41.4 & 13.2 & 13.2 \\
\hline 146 & Fosthiazate & $195>103$ & 14.7 & 86.3 & 8.0 & 25.6 & 91.0 & 16.3 & 19.4 & 75.2 & 14.4 & 14.9 \\
\hline 147 & Fthalide & $243>215$ & 14.6 & 81.0 & 8.1 & 9.4 & 79.0 & 8.7 & 9.5 & 83.4 & 3.9 & 6.5 \\
\hline 148 & Furametpyr metabolite & $296>278$ & 19.4 & 54.5 & 19.2 & 25.1 & 63.5 & 15.7 & 22.1 & 72.6 & 5.7 & 13.0 \\
\hline 149 & Furilazole & $262>220$ & 11.8 & 80.3 & 6.9 & 10.5 & 78.5 & 8.9 & 15.2 & 58.8 & 4.4 & 7.0 \\
\hline 150 & Halfenprox & $263>235$ & 21.3 & 84.0 & 2.1 & 9.2 & 76.8 & 4.7 & 5.6 & 71.3 & 2.4 & 3.9 \\
\hline 151 & Heptachlor & $272>237$ & 13.6 & 83.8 & 8.0 & 15.7 & 71.9 & 6.1 & 7.7 & 76.2 & 4.2 & 6.9 \\
\hline 152 & Heptachlor epoxide A & $183>155$ & 15.1 & 80.7 & 23.8 & 28.4 & 81.2 & 27.0 & 37.6 & 72.6 & 14.0 & 15.4 \\
\hline 153 & Heptachlor epoxide B & $353>263$ & 15.1 & 89.1 & 10.8 & 15.2 & 80.5 & 12.3 & 15.3 & 85.2 & 11.3 & 11.3 \\
\hline 154 & Hexachlorobenzene & $284>249$ & 11.5 & 43.7 & 11.2 & 16.8 & 40.6 & 6.5 & 23.1 & 56.8 & 8.5 & 9.8 \\
\hline 155 & Hexaconazole & $214>172$ & 16.0 & 75.3 & 15.5 & 28.7 & 86.4 & 15.6 & 15.6 & 82.2 & 11.3 & 12.2 \\
\hline 156 & Iodofenphos & $377>362$ & 15.9 & 82.0 & 3.9 & 8.7 & 77.2 & 5.0 & 10.9 & 79.1 & 2.5 & 4.2 \\
\hline 157 & Iprobenfos & $204>122$ & 12.8 & 84.1 & 12.1 & 16.8 & 86.6 & 8.2 & 10.1 & 80.3 & 6.8 & 6.8 \\
\hline 158 & Iprodione & $314>245$ & 18.4 & 84.0 & 9.5 & 16.6 & 81.2 & 6.2 & 15.3 & 73.8 & 6.7 & 12.2 \\
\hline 159 & Iprodione metabolite & $329>127$ & 19.0 & 107.5 & 16.2 & 23.0 & 93.9 & 19.1 & 23.0 & 78.9 & 17.6 & 19.2 \\
\hline 160 & Isazophos & $257>162$ & 12.6 & 86.6 & 9.5 & 13.6 & 82.1 & 7.0 & 9.2 & 82.5 & 4.7 & 7.4 \\
\hline 161 & Isocarbophos & $136>108$ & 14.4 & 84.6 & 5.2 & 7.3 & 83.8 & 4.2 & 6.3 & 79.7 & 5.3 & 6.1 \\
\hline 162 & Isofenphos & $213>121$ & 15.0 & 95.9 & 7.3 & 16.0 & 87.5 & 9.3 & 10.1 & 88.3 & 7.3 & 18.8 \\
\hline 163 & Isofenphos oxon & $229>201$ & 14.4 & 89.2 & 3.4 & 17.1 & 78.1 & 5.1 & 5.1 & 82.1 & 5.2 & 6.2 \\
\hline 164 & Isofenphos methyl & $199>121$ & 14.7 & 84.3 & 5.4 & 8.0 & 81.0 & 6.2 & 9.1 & 78.3 & 6.5 & 6.9 \\
\hline 165 & Isoprocarb & $121>103$ & 9.6 & 85.5 & 3.5 & 5.5 & 84.7 & 3.9 & 6.0 & 81.6 & 4.3 & 4.9 \\
\hline 166 & Isoprothiolane & $290>118$ & 16.0 & 82.4 & 7.2 & 10.1 & 84.2 & 8.3 & 10.4 & 80.3 & 6.6 & 13.2 \\
\hline 167 & Isoxadifen ethyl & $294>204$ & 17.3 & 83.7 & 7.6 & 11.4 & 76.3 & 4.5 & 9.3 & 81.7 & 7.7 & 9.8 \\
\hline 168 & Isoxathion & $177>130$ & 16.5 & 96.0 & 4.3 & 9.5 & 91.8 & 5.8 & 18.3 & 77.7 & 5.0 & 6.0 \\
\hline 169 & Kresoxim methyl & $206>131$ & 16.3 & 85.5 & 9.3 & 14.5 & 81.0 & 7.4 & 15.9 & 82.0 & 8.9 & 8.9 \\
\hline 170 & Lenacil & $153>136$ & 17.6 & 86.7 & 3.8 & 11.5 & 82.7 & 4.9 & 9.8 & 85.5 & 5.0 & 9.8 \\
\hline 171 & Leptophos & $377>269$ & 19.2 & 85.6 & 5.7 & 12.7 & 71.0 & 9.1 & 10.4 & 77.3 & 3.4 & 6.5 \\
\hline 172 & Malathion & $173>99$ & 14.0 & 87.2 & 6.1 & 9.2 & 80.6 & 5.7 & 8.6 & 81.1 & 3.9 & 4.1 \\
\hline 173 & MCP ethyl ester & $228>141$ & 10.6 & 81.5 & 3.4 & 11.5 & 59.3 & 5.1 & 15.8 & 80.1 & 5.4 & 5.4 \\
\hline 174 & MCPB ethyl & $115>87$ & 13.0 & 89.2 & 4.3 & 10.0 & 80.7 & 2.6 & 8.1 & 84.9 & 6.3 & 6.3 \\
\hline 175 & Mecarbam & $131>86$ & 15.1 & 89.1 & 31.2 & 31.2 & 94.8 & 15.2 & 19.5 & 79.5 & 12.2 & 12.2 \\
\hline 176 & Mefenacet & $192>136$ & 19.4 & 85.2 & 2.6 & 10.4 & 82.4 & 2.8 & 4.2 & 82.4 & 3.5 & 5.7 \\
\hline 177 & Mepronil & $119>91$ & 17.2 & 87.0 & 4.2 & 21.1 & 97.3 & 5.2 & 27.9 & 86.7 & 5.9 & 6.9 \\
\hline 178 & Metalaxyl & $249>190$ & 13.5 & 74.8 & 13.5 & 28.4 & 89.7 & 12.0 & 12.9 & 82.8 & 8.4 & 11.1 \\
\hline 179 & Methacrifos & $208>180$ & 9.2 & 82.6 & 2.7 & 6.7 & 77.8 & 1.7 & 6.1 & 77.2 & 5.6 & 8.9 \\
\hline 180 & Methidathion & $145>85$ & 15.4 & 86.7 & 5.5 & 9.5 & 81.9 & 4.5 & 8.7 & 84.0 & 7.3 & 7.7 \\
\hline 181 & Methoxychlor & $227>169$ & 18.7 & 88.1 & 2.7 & 8.0 & 81.0 & 2.6 & 8.3 & 78.1 & 3.4 & 6.1 \\
\hline 182 & Metolachlor & $238>162$ & 14.2 & 83.5 & 4.2 & 9.1 & 82.6 & 3.8 & 8.0 & 83.5 & 4.8 & 5.2 \\
\hline 183 & Metolcarb & $108>107$ & 8.8 & 85.9 & 3.9 & 6.6 & 85.4 & 2.4 & 5.8 & 78.6 & 4.4 & 6.2 \\
\hline 184 & Metribuzin & $198>82$ & 13.3 & 81.1 & 4.2 & 11.2 & 79.3 & 5.4 & 15.0 & 83.0 & 7.2 & 9.2 \\
\hline 185 & Mevinphos & $192>127$ & 8.3 & 84.1 & 3.8 & 4.8 & 81.8 & 2.3 & 3.8 & 75.2 & 5.4 & 7.9 \\
\hline 186 & Mirex & $272>237$ & 19.7 & 72.2 & 4.7 & 10.0 & 56.2 & 3.7 & 9.2 & 74.1 & 4.6 & 5.3 \\
\hline 187 & Molinate & $126>55$ & 9.7 & 78.1 & 6.4 & 11.5 & 73.9 & 4.7 & 7.5 & 78.4 & 7.5 & 7.8 \\
\hline 188 & Monocrotophos & $192>127$ & 11.2 & 83.4 & 10.6 & 12.6 & 84.7 & 14.0 & 15.3 & 74.5 & 10.1 & 10.1 \\
\hline 189 & Myclobutanil & $179>125$ & 16.2 & 86.0 & 7.7 & 10.6 & 86.9 & 5.6 & 7.2 & 82.7 & 6.3 & 8.5 \\
\hline 190 & Naled & $145>109$ & 6.5 & 60.4 & 10.9 & 10.9 & 43.1 & 9.8 & 23.2 & 61.0 & 7.2 & 17.2 \\
\hline 191 & Napropamide & $271>72$ & 15.9 & 80.8 & 5.6 & 11.6 & 86.9 & 6.9 & 9.1 & 80.3 & 7.2 & 10.5 \\
\hline 192 & Nitralin & $274>169$ & 18.0 & 87.5 & 10.7 & 15.0 & 86.5 & 5.7 & 13.8 & 73.9 & 7.7 & 7.7 \\
\hline 193 & Nitrapyrin & $196>112$ & 8.7 & 74.4 & 7.5 & 12.9 & 72.1 & 7.2 & 16.2 & 71.2 & 10.6 & 10.6 \\
\hline 194 & Nitrofen & $283>202$ & 16.6 & 104.6 & 6.3 & 27.4 & 92.2 & 9.3 & 22.0 & 74.9 & 7.6 & 7.6 \\
\hline 195 & Nitrothal isopropyl & $236>194$ & 14.5 & 89.8 & 2.0 & 9.6 & 86.2 & 2.4 & 4.3 & 76.4 & 3.3 & 4.4 \\
\hline 196 & Norflurazon & $303>145$ & 17.5 & 87.5 & 6.9 & 11.1 & 87.7 & 5.7 & 5.7 & 83.2 & 5.3 & 8.1 \\
\hline 197 & $o, p$-DDT & $237>165$ & 17.0 & 80.3 & 11.0 & 17.2 & 71.8 & 1.7 & 8.4 & 78.4 & 7.2 & 8.0 \\
\hline 198 & Orthobencarb & $222>100$ & 13.9 & 82.1 & 6.1 & 12.6 & 75.0 & 4.3 & 9.5 & 83.8 & 2.4 & 5.6 \\
\hline 199 & Oxadiazon & $258>175$ & 16.1 & 82.9 & 10.6 & 15.8 & 77.0 & 6.0 & 10.3 & 79.0 & 7.2 & 10.8 \\
\hline 200 & Oxadixyl & $163>132$ & 16.9 & 81.2 & 5.1 & 10.9 & 80.5 & 3.0 & 6.1 & 84.8 & 4.5 & 5.3 \\
\hline 201 & Oxpoconazole fumarate & $294>202$ & 11.1 & 80.0 & 8.3 & 11.8 & 74.2 & 8.4 & 13.7 & 76.5 & 5.1 & 7.4 \\
\hline 202 & Oxyfluorfen & $361>300$ & 16.2 & 95.6 & 11.5 & 23.1 & 90.4 & 5.8 & 12.2 & 75.3 & 9.4 & 11.1 \\
\hline 203 & $p, p$-DDD & $237>165$ & 17.7 & 87.4 & 2.8 & 7.1 & 76.8 & 5.1 & 7.0 & 81.2 & 4.7 & 6.4 \\
\hline 204 & $p, p$-DDE & $246>176$ & 16.2 & 79.5 & 6.7 & 8.6 & 64.9 & 2.4 & 10.5 & 78.8 & 3.9 & 6.1 \\
\hline 205 & $p, p$-DDT & $237>165$ & 17.0 & 84.6 & 3.0 & 8.2 & 75.0 & 2.6 & 5.8 & 79.3 & 3.2 & 4.2 \\
\hline 206 & Paclobutrazol & $236>125$ & 15.6 & 81.1 & 5.8 & 10.5 & 77.2 & 6.6 & 8.3 & 82.1 & 3.5 & 7.9 \\
\hline 207 & Parathion & $291>109$ & 13.4 & 93.2 & 5.2 & 11.8 & 88.3 & 5.7 & 6.8 & 80.8 & 7.1 & 7.1 \\
\hline
\end{tabular}


Continued.

\begin{tabular}{|c|c|c|c|c|c|c|c|c|c|c|c|c|c|c|}
\hline \multirow{2}{*}{\multicolumn{3}{|c|}{$\begin{array}{c}\text { FASRAC } \\
\text { Apple }\end{array}$}} & \multicolumn{12}{|c|}{ Official method } \\
\hline & & & \multicolumn{3}{|c|}{ Wheat flour } & \multicolumn{3}{|c|}{ Soy beans } & \multicolumn{3}{|c|}{ Spinach } & \multicolumn{3}{|c|}{ Apple } \\
\hline $\begin{array}{c}\text { Recovery } \\
(\%)\end{array}$ & $\begin{array}{c}\mathrm{RSD}_{1}{ }^{*} \\
(\%)\end{array}$ & $\begin{array}{c}\mathrm{RSD}_{2}{ }^{* *} \\
(\%)\end{array}$ & $\begin{array}{c}\text { Recovery } \\
(\%)\end{array}$ & $\begin{array}{c}\mathrm{RSD}_{1}{ }^{*} \\
(\%)\end{array}$ & $\begin{array}{c}\mathrm{RSD}_{2}{ }^{* *} \\
(\%)\end{array}$ & $\begin{array}{c}\text { Recovery } \\
(\%)\end{array}$ & $\begin{array}{c}\mathrm{RSD}_{1}{ }^{*} \\
(\%)\end{array}$ & $\begin{array}{c}\mathrm{RSD}_{2}{ }^{* *} \\
(\%)\end{array}$ & $\begin{array}{c}\text { Recovery } \\
(\%)\end{array}$ & $\begin{array}{c}\mathrm{RSD}_{1}{ }^{*} \\
(\%)\end{array}$ & $\begin{array}{c}\mathrm{RSD}_{2}{ }^{* *} \\
(\%)\end{array}$ & $\begin{array}{c}\text { Recovery } \\
(\%)\end{array}$ & $\begin{array}{c}\mathrm{RSD}_{1}{ }^{*} \\
(\%)\end{array}$ & $\begin{array}{c}\mathrm{RSD}_{2}{ }^{* *} \\
(\%)\end{array}$ \\
\hline 82.5 & 3.9 & 5.3 & 84.8 & 2.3 & 13.6 & 80.7 & 2.8 & 9.5 & 86.2 & 3.5 & 7.2 & 87.5 & 2.5 & 7.9 \\
\hline 85.3 & 5.4 & 6.5 & 82.5 & 7.9 & 12.1 & 78.9 & 3.4 & 17.7 & 83.0 & 4.6 & 7.5 & 89.6 & 4.4 & 6.4 \\
\hline 70.6 & 3.4 & 6.6 & 66.5 & 3.8 & 11.9 & 71.4 & 3.5 & 10.3 & 69.7 & 3.6 & 8.9 & 76.0 & 5.4 & 9.5 \\
\hline 84.6 & 3.9 & 6.3 & 86.3 & 3.5 & 9.0 & 76.0 & 5.0 & 19.6 & 85.6 & 3.1 & 5.9 & 89.3 & 4.3 & 5.4 \\
\hline 82.6 & 2.6 & 3.9 & 87.4 & 1.4 & 8.9 & 76.3 & 2.2 & 11.6 & 80.8 & 4.5 & 5.9 & 91.6 & 3.4 & 4.2 \\
\hline 82.7 & 5.3 & 11.3 & 78.7 & 3.6 & 12.8 & 70.4 & 9.7 & 11.0 & 84.9 & 3.7 & 9.2 & 88.0 & 8.5 & 8.5 \\
\hline 48.2 & 12.7 & 26.1 & 39.8 & 6.1 & 20.8 & 42.7 & 10.8 & 13.4 & 39.0 & 10.8 & 14.0 & 50.7 & 1.9 & 14.2 \\
\hline 82.5 & 7.0 & 11.0 & 93.1 & 10.2 & 17.0 & 88.5 & 14.1 & 14.1 & 86.7 & 5.0 & 6.6 & 90.3 & 10.0 & 10.0 \\
\hline 82.0 & 4.0 & 8.1 & 78.9 & 6.7 & 14.5 & 77.5 & 3.6 & 17.2 & 88.5 & 3.1 & 5.0 & 90.3 & 3.6 & 4.5 \\
\hline 67.0 & 12.6 & 14.1 & 39.5 & 8.2 & 28.1 & 60.8 & 6.0 & 19.8 & 63.2 & 3.0 & 6.7 & 71.7 & 13.5 & 16.5 \\
\hline 78.2 & 6.8 & 11.1 & 81.5 & 5.2 & 13.7 & 70.4 & 25.6 & 35.6 & 56.7 & 3.9 & 8.5 & 77.7 & 5.1 & 19.4 \\
\hline 80.1 & 3.9 & 4.5 & 79.5 & 3.0 & 8.9 & 66.6 & 4.4 & 12.7 & 76.6 & 4.7 & 6.1 & 88.5 & 4.0 & 5.0 \\
\hline 80.4 & 4.2 & 7.5 & 76.5 & 3.4 & 15.3 & 63.7 & 4.3 & 20.9 & 86.7 & 5.0 & 7.8 & 88.6 & 4.2 & 5.6 \\
\hline 82.8 & 13.4 & 20.1 & 73.0 & 20.6 & 27.9 & 62.8 & 10.5 & 32.8 & 93.8 & 7.5 & 7.6 & 94.1 & 7.1 & 7.9 \\
\hline 87.9 & 6.9 & 9.9 & 78.0 & 12.7 & 17.5 & 68.1 & 10.1 & 16.2 & 85.8 & 7.3 & 8.5 & 84.5 & 5.7 & 5.7 \\
\hline 43.9 & 4.4 & 15.6 & 44.4 & 13.9 & 54.0 & 27.6 & 9.3 & 25.7 & 60.2 & 8.3 & 15.3 & 46.2 & 16.2 & 28.6 \\
\hline 81.8 & 9.9 & 9.9 & 82.8 & 19.4 & 32.3 & 83.8 & 6.9 & 8.4 & 83.0 & 9.0 & 11.5 & 86.1 & 7.2 & 8.5 \\
\hline 83.2 & 3.4 & 7.3 & 83.7 & 3.3 & 7.1 & 72.3 & 4.2 & 12.2 & 86.4 & 1.2 & 4.9 & 88.8 & 3.4 & 5.6 \\
\hline 82.7 & 6.5 & 6.5 & 84.4 & 6.9 & 16.6 & 83.6 & 5.9 & 12.0 & 88.1 & 4.5 & 5.3 & 88.0 & 4.2 & 7.2 \\
\hline 78.6 & 7.7 & 7.7 & 89.3 & 3.1 & 11.1 & 84.9 & 6.5 & 15.3 & 77.0 & 6.4 & 8.1 & 85.2 & 4.6 & 4.6 \\
\hline 71.0 & 24.4 & 24.4 & 93.4 & 19.8 & 24.0 & 104.8 & 19.6 & 29.9 & 80.1 & 8.7 & 12.2 & 92.1 & 23.2 & 23.2 \\
\hline 82.2 & 6.0 & 11.5 & 86.3 & 8.6 & 15.4 & 74.0 & 8.5 & 17.1 & 88.2 & 10.2 & 11.5 & 89.6 & 5.5 & 6.6 \\
\hline 78.0 & 2.8 & 7.1 & 81.0 & 6.2 & 10.1 & 78.5 & 3.8 & 8.6 & 83.4 & 3.6 & 3.8 & 85.0 & 3.8 & 4.3 \\
\hline 88.5 & 3.9 & 6.9 & 85.7 & 4.2 & 11.1 & 80.2 & 6.2 & 15.3 & 85.3 & 2.9 & 6.4 & 95.9 & 3.4 & 8.2 \\
\hline 83.6 & 4.7 & 5.5 & 82.9 & 5.0 & 10.7 & 78.2 & 4.3 & 14.2 & 87.3 & 2.8 & 5.7 & 89.9 & 2.5 & 3.9 \\
\hline 81.1 & 3.9 & 5.2 & 84.2 & 2.5 & 11.9 & 86.7 & 3.3 & 8.0 & 84.4 & 2.9 & 5.8 & 90.7 & 4.9 & 6.0 \\
\hline 82.7 & 3.5 & 5.2 & 88.1 & 2.3 & 14.2 & 85.5 & 2.4 & 12.2 & 87.0 & 4.2 & 6.3 & 89.3 & 3.0 & 4.5 \\
\hline 82.9 & 8.2 & 10.6 & 80.8 & 10.7 & 18.7 & 78.8 & 6.6 & 17.1 & 88.0 & 8.7 & 8.7 & 88.4 & 4.7 & 9.4 \\
\hline 79.3 & 5.8 & 7.6 & 81.9 & 7.0 & 11.1 & 81.3 & 4.6 & 10.1 & 85.3 & 4.2 & 4.9 & 89.1 & 4.4 & 5.4 \\
\hline 85.0 & 5.2 & 5.2 & 93.4 & 3.7 & 11.2 & 87.8 & 7.4 & 10.3 & 78.3 & 3.4 & 12.6 & 90.6 & 4.3 & 9.4 \\
\hline 86.0 & 11.6 & 11.6 & 83.3 & 7.3 & 11.0 & 82.9 & 5.8 & 13.4 & 86.7 & 2.2 & 2.4 & 92.2 & 2.2 & 5.1 \\
\hline 83.3 & 3.8 & 4.9 & 80.1 & 4.2 & 12.2 & 78.0 & 4.5 & 9.4 & 80.4 & 4.7 & 8.8 & 85.2 & 4.1 & 7.6 \\
\hline 84.9 & 4.4 & 5.6 & 76.1 & 4.2 & 13.2 & 61.6 & 4.3 & 20.7 & 81.8 & 3.6 & 4.6 & 88.4 & 5.5 & 6.0 \\
\hline 80.8 & 2.9 & 5.4 & 83.5 & 4.1 & 12.7 & 83.9 & 4.1 & 9.2 & 84.1 & 2.2 & 7.1 & 89.3 & 3.2 & 4.4 \\
\hline 79.6 & 4.3 & 7.8 & 85.4 & 3.4 & 20.1 & 50.2 & 7.1 & 18.9 & 88.1 & 3.5 & 12.4 & 89.5 & 3.2 & 9.2 \\
\hline 78.4 & 8.3 & 9.3 & 83.9 & 6.8 & 16.1 & 76.9 & 7.3 & 13.5 & 86.9 & 6.5 & 7.8 & 87.0 & 4.2 & 4.8 \\
\hline 83.9 & 10.4 & 11.5 & 77.6 & 7.1 & 38.6 & 85.0 & 23.6 & 23.6 & 91.1 & 9.1 & 12.3 & 88.4 & 6.2 & 16.9 \\
\hline 83.4 & 3.0 & 5.0 & 85.7 & 1.2 & 9.8 & 83.1 & 2.9 & 8.9 & 84.8 & 2.2 & 5.7 & 89.8 & 2.4 & 3.2 \\
\hline 84.2 & 9.1 & 13.6 & 79.4 & 1.3 & 10.7 & 76.2 & 2.4 & 13.5 & 83.2 & 3.3 & 9.0 & 80.2 & 3.6 & 8.3 \\
\hline 83.9 & 7.7 & 14.0 & 84.8 & 10.0 & 13.9 & 86.6 & 5.2 & 21.7 & 87.5 & 4.6 & 9.6 & 93.5 & 5.5 & 6.8 \\
\hline 77.0 & 3.1 & 4.1 & 78.5 & 2.5 & 20.3 & 76.3 & 3.4 & 14.5 & 82.3 & 9.8 & 9.8 & 80.9 & 4.1 & 8.8 \\
\hline 83.6 & 3.1 & 5.8 & 85.5 & 2.7 & 8.8 & 81.2 & 3.4 & 8.6 & 87.3 & 2.5 & 4.1 & 89.7 & 2.8 & 4.3 \\
\hline 81.6 & 4.4 & 4.4 & 86.4 & 1.3 & 11.1 & 79.6 & 3.9 & 8.8 & 82.3 & 2.7 & 7.1 & 89.0 & 3.3 & 5.2 \\
\hline 82.0 & 4.9 & 7.3 & 83.3 & 1.9 & 14.0 & 81.6 & 2.5 & 11.8 & 86.9 & 2.4 & 6.2 & 90.1 & 2.7 & 5.7 \\
\hline 81.8 & 2.3 & 3.7 & 89.9 & 2.3 & 15.8 & 86.1 & 3.0 & 14.1 & 84.3 & 4.7 & 6.6 & 88.3 & 1.7 & 5.1 \\
\hline 85.9 & 2.9 & 8.5 & 79.9 & 5.2 & 16.1 & 79.4 & 6.7 & 10.3 & 85.5 & 6.4 & 8.6 & 78.0 & 7.7 & 33.3 \\
\hline 79.7 & 2.5 & 3.4 & 82.3 & 3.3 & 17.5 & 78.0 & 1.9 & 12.4 & 80.5 & 7.7 & 7.7 & 84.9 & 5.6 & 6.6 \\
\hline 82.8 & 2.5 & 5.0 & 67.1 & 2.4 & 18.4 & 41.0 & 6.1 & 26.3 & 77.9 & 1.5 & 3.4 & 89.0 & 2.5 & 4.3 \\
\hline 76.7 & 2.8 & 5.1 & 74.0 & 3.5 & 24.6 & 74.8 & 3.7 & 37.4 & 84.4 & 2.5 & 9.6 & 81.0 & 2.1 & 9.4 \\
\hline 75.3 & 4.4 & 4.7 & 73.7 & 7.4 & 11.7 & 72.4 & 4.8 & 8.7 & 68.7 & 8.8 & 10.3 & 77.2 & 1.7 & 9.6 \\
\hline 82.6 & 5.5 & 7.9 & 83.8 & 3.7 & 7.8 & 87.1 & 3.3 & 17.7 & 85.6 & 2.4 & 4.1 & 89.0 & 3.2 & 5.9 \\
\hline 50.5 & 10.1 & 11.4 & 44.8 & 8.9 & 19.7 & 29.1 & 9.0 & 27.6 & 56.8 & 5.8 & 16.2 & 50.9 & 5.6 & 15.1 \\
\hline 87.7 & 7.1 & 13.2 & 89.0 & 7.5 & 13.5 & 76.4 & 12.9 & 22.0 & 87.3 & 4.0 & 4.0 & 88.2 & 3.6 & 8.9 \\
\hline 78.6 & 10.2 & 10.2 & 88.0 & 10.1 & 12.2 & 78.1 & 16.6 & 18.6 & 69.4 & 5.8 & 12.7 & 78.4 & 4.6 & 6.9 \\
\hline 69.7 & 5.0 & 5.0 & 69.8 & 7.1 & 28.8 & 69.8 & 9.4 & 15.2 & 75.6 & 8.7 & 11.0 & 69.6 & 6.5 & 10.6 \\
\hline 79.0 & 5.1 & 7.4 & 66.8 & 9.2 & 36.2 & 64.3 & 8.1 & 33.4 & 80.8 & 2.7 & 5.6 & 83.4 & 6.0 & 6.0 \\
\hline 79.9 & 2.7 & 3.9 & 83.6 & 2.7 & 9.5 & 81.0 & 4.6 & 10.7 & 79.8 & 3.5 & 6.8 & 83.7 & 2.7 & 4.7 \\
\hline 81.8 & 5.7 & 5.7 & 82.9 & 5.2 & 11.7 & 79.3 & 5.1 & 9.3 & 86.2 & 3.7 & 4.6 & 89.2 & 3.1 & 5.8 \\
\hline 83.3 & 3.5 & 6.7 & 80.2 & 11.8 & 12.8 & 64.5 & 2.6 & 19.5 & 84.7 & 2.1 & 3.7 & 90.0 & 3.1 & 5.4 \\
\hline 84.0 & 4.3 & 7.4 & 86.3 & 3.1 & 10.1 & 77.0 & 3.7 & 14.3 & 87.1 & 2.3 & 9.4 & 91.1 & 3.6 & 6.5 \\
\hline 85.8 & 4.9 & 8.5 & 81.9 & 3.8 & 15.2 & 74.4 & 10.3 & 14.1 & 84.4 & 7.0 & 7.0 & 87.6 & 6.4 & 8.9 \\
\hline 83.6 & 5.4 & 6.2 & 84.8 & 2.9 & 9.2 & 78.4 & 5.4 & 12.4 & 86.6 & 1.7 & 5.2 & 90.0 & 4.7 & 5.4 \\
\hline 80.7 & 5.4 & 7.8 & 90.6 & 8.8 & 17.9 & 86.7 & 7.5 & 14.7 & 84.1 & 7.7 & 12.1 & 89.7 & 6.1 & 8.7 \\
\hline 78.9 & 6.9 & 7.6 & 86.3 & 9.6 & 18.5 & 85.2 & 6.2 & 18.3 & 79.3 & 8.8 & 12.3 & 85.1 & 5.5 & 6.5 \\
\hline 82.9 & 4.5 & 5.4 & 82.6 & 6.3 & 11.6 & 64.9 & 3.8 & 8.8 & 76.3 & 2.0 & 11.7 & 83.5 & 1.7 & 7.1 \\
\hline 84.0 & 6.0 & 6.0 & 74.7 & 2.3 & 18.5 & 55.6 & 3.2 & 21.3 & 84.4 & 3.4 & 4.6 & 91.4 & 2.7 & 5.1 \\
\hline 83.3 & 3.2 & 4.4 & 76.7 & 3.6 & 14.2 & 60.6 & 3.5 & 13.0 & 82.0 & 3.0 & 6.6 & 86.9 & 3.1 & 5.6 \\
\hline 82.8 & 4.4 & 8.1 & 85.3 & 4.9 & 10.3 & 77.6 & 5.0 & 8.9 & 85.4 & 1.8 & 3.5 & 89.4 & 2.4 & 5.9 \\
\hline 82.1 & 7.0 & 7.8 & 83.3 & 5.4 & 10.5 & 86.1 & 5.7 & 7.3 & 83.3 & 5.8 & 6.8 & 88.4 & 3.9 & 6.7 \\
\hline
\end{tabular}


Table 1

\begin{tabular}{|c|c|c|c|c|c|c|c|c|c|c|c|c|}
\hline \multirow{3}{*}{ No. } & \multirow{3}{*}{ Pesticides } & \multirow{3}{*}{$\begin{array}{c}\text { MRM } \\
\text { transitions } \\
\quad(\mathrm{m} / \mathrm{z})\end{array}$} & \multirow{3}{*}{$\begin{array}{c}\mathrm{RT} \\
(\mathrm{min})\end{array}$} & \multicolumn{9}{|c|}{ FASRAC } \\
\hline & & & & \multicolumn{3}{|c|}{ Wheat flour } & \multicolumn{3}{|c|}{ Soy beans } & & Spinach & \\
\hline & & & & $\begin{array}{c}\text { Recovery } \\
(\%)\end{array}$ & $\begin{array}{c}\mathrm{RSD}_{1}^{*} \\
(\%)\end{array}$ & $\begin{array}{c}\mathrm{RSD}_{2}^{* *} \\
(\%)\end{array}$ & $\begin{array}{c}\text { Recovery } \\
(\%)\end{array}$ & $\begin{array}{c}\mathrm{RSD}_{1}^{*} \\
(\%)\end{array}$ & $\begin{array}{c}\mathrm{RSD}_{2}^{* *} \\
(\%)\end{array}$ & $\begin{array}{c}\text { Recovery } \\
(\%)\end{array}$ & $\begin{array}{c}\mathrm{RSD}_{1}^{*} \\
(\%)\end{array}$ & $\begin{array}{c}\mathrm{RSD}_{2}{ }^{* *} \\
(\%)\end{array}$ \\
\hline 208 & Parathion methyl & $263>109$ & 14.3 & 91.4 & 6.1 & 12.2 & 86.8 & 11.8 & 11.8 & 73.3 & 7.5 & 7.5 \\
\hline 209 & Penconazole & $248>157$ & 15.0 & 83.3 & 4.8 & 20.4 & 79.2 & 5.0 & 17.0 & 82.8 & 4.2 & 6.0 \\
\hline 210 & Pendimethalin & $252>162$ & 14.8 & 87.7 & 9.2 & 11.0 & 81.9 & 3.4 & 6.3 & 75.4 & 8.0 & 8.8 \\
\hline 211 & Pentachloroaniline & $265>194$ & 13.0 & 81.3 & 9.1 & 15.5 & 71.3 & 7.3 & 9.7 & 82.7 & 10.3 & 10.3 \\
\hline 212 & Permethrin & $183>168$ & 20.5 & 91.4 & 3.5 & 13.1 & 74.1 & 5.2 & 5.2 & 78.4 & 3.6 & 3.9 \\
\hline 213 & Perthane & $223>167$ & 16.6 & 94.0 & 5.1 & 17.7 & 82.5 & 3.6 & 8.9 & 78.4 & 4.6 & 5.3 \\
\hline 214 & Phenothiol & $155>125$ & 12.7 & 70.0 & 7.9 & 10.8 & 46.7 & 6.8 & 14.7 & 70.3 & 3.0 & 4.5 \\
\hline 215 & Phenothrin & $183>153$ & 19.1 & 78.6 & 4.7 & 6.6 & 78.0 & 14.6 & 14.6 & 76.1 & 7.1 & 8.0 \\
\hline 216 & Phenthoate & $274>121$ & 15.2 & 79.0 & 8.4 & 12.3 & 73.7 & 8.2 & 8.5 & 82.5 & 4.3 & 6.4 \\
\hline 217 & Phorate & $260>75$ & 11.3 & 79.7 & 9.2 & 11.9 & 71.4 & 9.6 & 12.0 & 68.3 & 10.1 & 11.5 \\
\hline 218 & Phosalone & $182>111$ & 19.2 & 93.1 & 7.0 & 16.0 & 85.2 & 1.8 & 5.6 & 78.9 & 4.8 & 5.9 \\
\hline 219 & Phosmet & $160>77$ & 18.5 & 84.0 & 5.6 & 7.5 & 82.0 & 3.9 & 6.3 & 77.3 & 5.1 & 5.1 \\
\hline 220 & Phosphamidon & $264>127$ & 13.1 & 83.8 & 6.6 & 12.3 & 81.8 & 11.9 & 12.1 & 75.4 & 9.3 & 9.3 \\
\hline 221 & Piperonyl butoxide & $176>131$ & 18.0 & 85.9 & 3.0 & 3.2 & 80.2 & 4.6 & 5.3 & 79.8 & 3.5 & 4.5 \\
\hline 222 & Piperophos & $320>122$ & 18.6 & 82.0 & 3.0 & 7.6 & 80.3 & 4.6 & 6.7 & 77.8 & 5.5 & 6.2 \\
\hline 223 & Pirimiphos ethyl & $304>168$ & 14.6 & 85.4 & 8.9 & 8.9 & 78.6 & 6.1 & 7.1 & 81.3 & 4.6 & 4.6 \\
\hline 224 & Pirimiphos methyl & $290>233$ & 13.8 & 84.2 & 15.9 & 17.0 & 75.2 & 13.9 & 19.2 & 81.4 & 15.5 & 15.5 \\
\hline 225 & Pretilachlor & $238>146$ & 16.0 & 87.9 & 7.7 & 14.0 & 74.2 & 5.4 & 6.1 & 81.4 & 2.4 & 8.1 \\
\hline 226 & Prochloraz & $308>195$ & 20.5 & 85.9 & 3.6 & 7.4 & 79.7 & 4.3 & 8.2 & 71.6 & 3.5 & 5.8 \\
\hline 227 & Profenofos & $337>267$ & 16.1 & 81.1 & 9.4 & 9.4 & 78.3 & 7.9 & 14.0 & 78.7 & 6.5 & 6.5 \\
\hline 228 & Prometon & $225>168$ & 11.8 & 82.7 & 8.2 & 18.7 & 75.3 & 9.3 & 10.0 & 85.5 & 5.6 & 5.6 \\
\hline 229 & Prometryn & $226>184$ & 13.6 & 82.5 & 9.4 & 10.3 & 79.6 & 8.1 & 11.0 & 83.0 & 7.2 & 7.2 \\
\hline 230 & Propachlor & $196>120$ & 10.4 & 83.5 & 4.9 & 7.1 & 83.9 & 2.5 & 4.3 & 81.1 & 4.8 & 5.0 \\
\hline 231 & Propanil & $161>99$ & 13.2 & 83.5 & 8.3 & 10.3 & 82.1 & 3.9 & 8.4 & 82.6 & 6.8 & 6.8 \\
\hline 232 & Propaphos & $220>140$ & 15.5 & 81.0 & 3.2 & 5.2 & 72.4 & 3.2 & 9.2 & 70.5 & 2.1 & 8.2 \\
\hline 233 & Propargite & $135>107$ & 18.0 & 81.8 & 10.7 & 12.8 & 72.5 & 7.2 & 9.2 & 81.3 & 7.1 & 8.8 \\
\hline 234 & Propazine & $214>172$ & 12.0 & 77.4 & 6.7 & 11.6 & 76.6 & 7.1 & 9.6 & 83.8 & 5.7 & 6.3 \\
\hline 235 & Propetamphos & $194>166$ & 12.2 & 91.8 & 17.8 & 30.3 & 86.3 & 13.4 & 13.4 & 86.0 & 11.0 & 12.4 \\
\hline 236 & Propham & $179>137$ & 8.7 & 83.8 & 5.7 & 6.0 & 83.3 & 4.6 & 6.1 & 78.4 & 4.7 & 6.8 \\
\hline 237 & Propiconazole & $259>191$ & 17.6 & 84.9 & 6.8 & 8.4 & 75.3 & 15.4 & 15.4 & 83.4 & 10.9 & 11.0 \\
\hline 238 & Propoxur & $152>110$ & 10.4 & 86.3 & 4.6 & 7.0 & 86.3 & 3.0 & 5.3 & 81.9 & 3.6 & 3.8 \\
\hline 239 & Propyzamide & $173>145$ & 12.3 & 83.6 & 5.1 & 11.7 & 84.7 & 5.1 & 7.3 & 85.0 & 6.0 & 8.9 \\
\hline 240 & Prothiofos & $267>239$ & 16.0 & 77.5 & 6.8 & 8.5 & 70.3 & 7.2 & 10.8 & 78.1 & 5.9 & 9.2 \\
\hline 241 & Pyraclofos & $360>194$ & 20.0 & 86.9 & 2.8 & 8.4 & 83.1 & 1.9 & 3.0 & 82.0 & 3.3 & 5.9 \\
\hline 242 & Pyraflufen ethyl & $412>349$ & 17.6 & 82.4 & 5.6 & 11.0 & 82.6 & 6.9 & 8.5 & 83.4 & 6.8 & 8.2 \\
\hline 243 & Pyrazophos & $373>232$ & 19.7 & 88.4 & 5.2 & 12.0 & 82.0 & 4.9 & 12.8 & 82.1 & 6.1 & 7.3 \\
\hline 244 & Pyributicarb & $165>108$ & 18.3 & 86.2 & 2.4 & 5.7 & 80.5 & 2.7 & 4.6 & 76.9 & 3.7 & 6.0 \\
\hline 245 & Pyridaben & $147>117$ & 20.5 & 83.4 & 2.4 & 9.5 & 76.6 & 2.2 & 4.3 & 77.4 & 3.2 & 6.0 \\
\hline 246 & Pyridafenthion & $340>199$ & 18.4 & 89.8 & 5.6 & 18.6 & 90.8 & 2.3 & 6.5 & 81.7 & 6.3 & 10.9 \\
\hline 247 & Pyrimethanil & $198>156$ & 12.4 & 84.6 & 12.3 & 19.8 & 83.2 & 5.4 & 11.8 & 83.4 & 8.1 & 12.2 \\
\hline 248 & Pyriproxyfen & $136>96$ & 19.4 & 83.0 & 2.6 & 9.8 & 78.2 & 2.3 & 2.4 & 81.1 & 4.5 & 4.7 \\
\hline 249 & Pyroquilon & $173>130$ & 12.3 & 83.5 & 10.2 & 10.7 & 83.8 & 5.7 & 15.3 & 84.1 & 3.6 & 6.7 \\
\hline 250 & Quinalphos & $146>118$ & 15.2 & 83.8 & 6.1 & 14.2 & 82.0 & 5.8 & 9.7 & 83.1 & 3.2 & 7.0 \\
\hline 251 & Quinoclamine & $207>172$ & 14.1 & 85.4 & 6.0 & 8.7 & 87.9 & 3.9 & 7.0 & 79.7 & 5.0 & 5.3 \\
\hline 252 & Quinoxyfen & $237>208$ & 17.5 & 86.1 & 3.3 & 10.9 & 76.3 & 2.8 & 8.7 & 87.9 & 5.2 & 14.3 \\
\hline 253 & Quintozene & $249>214$ & 12.0 & 88.2 & 8.0 & 13.7 & 79.2 & 17.2 & 17.3 & 77.8 & 4.7 & 10.4 \\
\hline 254 & Salithion & $216>201$ & 11.1 & 78.4 & 5.3 & 17.7 & 77.2 & 8.2 & 12.2 & 82.6 & 6.4 & 6.5 \\
\hline 255 & Simazine & $201>138$ & 11.8 & 80.4 & 13.1 & 13.1 & 76.9 & 8.0 & 17.3 & 85.6 & 7.9 & 7.9 \\
\hline 256 & Simetryn & $213>170$ & 13.5 & 85.5 & 6.9 & 8.9 & 86.8 & 7.0 & 8.3 & 81.8 & 6.5 & 9.7 \\
\hline 257 & Spirodiclofen & $322>139$ & 17.2 & 83.2 & 6.7 & 10.1 & 62.3 & 14.4 & 14.4 & 68.6 & 7.1 & 8.0 \\
\hline 258 & Spiroxamine & $100>58$ & 13.4 & 70.4 & 20.2 & 20.2 & 63.9 & 14.6 & 20.3 & 76.9 & 10.3 & 10.8 \\
\hline 259 & Sulfotep & $322>202$ & 11.1 & 74.7 & 7.5 & 14.7 & 75.8 & 8.7 & 15.7 & 77.8 & 9.0 & 9.0 \\
\hline 260 & Sulprofos & $322>280$ & 17.2 & 78.9 & 13.8 & 13.8 & 61.0 & 13.3 & 18.0 & 65.2 & 5.7 & 11.6 \\
\hline 261 & Swep & $219>187$ & 11.9 & 81.9 & 8.2 & 14.9 & 80.2 & 4.7 & 5.4 & 82.2 & 5.2 & 6.0 \\
\hline 262 & ТСМТВ & $180>136$ & 15.9 & 88.4 & 5.3 & 10.4 & 72.8 & 7.1 & 8.5 & 48.9 & 9.8 & 12.7 \\
\hline 263 & Tebuconazole & $250>125$ & 17.9 & 81.3 & 2.6 & 8.3 & 79.9 & 4.7 & 8.5 & 82.7 & 5.5 & 8.3 \\
\hline 264 & Tebufenpyrad & $333>171$ & 18.8 & 85.8 & 5.9 & 10.2 & 81.7 & 3.1 & 4.5 & 80.7 & 5.9 & 8.1 \\
\hline 265 & Tebupirimfos & $318>152$ & 12.8 & 81.4 & 6.6 & 10.1 & 75.4 & 14.7 & 14.7 & 81.0 & 6.7 & 9.8 \\
\hline 266 & Tecnazene & $261>203$ & 10.2 & 81.6 & 5.2 & 6.2 & 74.5 & 4.3 & 9.8 & 77.0 & 3.5 & 5.4 \\
\hline 267 & Tefluthrin & $197>141$ & 12.6 & 83.1 & 13.4 & 13.4 & 75.1 & 6.5 & 8.7 & 77.4 & 4.9 & 4.9 \\
\hline 268 & Terbacil & $161>88$ & 12.6 & 85.5 & 11.4 & 13.0 & 82.4 & 10.9 & 10.9 & 80.0 & 4.7 & 7.8 \\
\hline 269 & Terbucarb & $220>205$ & 13.2 & 79.7 & 5.3 & 11.6 & 76.0 & 3.7 & 9.1 & 81.8 & 4.5 & 6.9 \\
\hline 270 & Terbufos & $231>175$ & 12.2 & 81.3 & 5.1 & 10.5 & 76.4 & 6.5 & 9.4 & 74.9 & 9.5 & 9.5 \\
\hline 271 & Terbutryn & $241>185$ & 13.9 & 83.7 & 5.8 & 8.0 & 81.3 & 4.8 & 6.1 & 81.9 & 3.8 & 7.6 \\
\hline 272 & Tetraconazole & $336>204$ & 14.4 & 84.5 & 9.3 & 12.2 & 82.1 & 13.3 & 18.1 & 81.4 & 8.9 & 9.8 \\
\hline 273 & Tetradifon & $227>199$ & 19.1 & 89.2 & 6.8 & 12.2 & 78.5 & 7.4 & 7.4 & 84.1 & 9.0 & 9.3 \\
\hline 274 & Tetramethrin & $164>107$ & 18.6 & 87.8 & 2.8 & 9.1 & 81.5 & 3.7 & 5.2 & 77.6 & 7.2 & 7.2 \\
\hline 275 & Thenylchlor & $288>141$ & 17.8 & 82.6 & 5.3 & 6.1 & 84.4 & 7.3 & 10.3 & 85.0 & 3.8 & 5.1 \\
\hline 276 & Thiazopyr & $327>277$ & 14.1 & 83.7 & 8.3 & 9.8 & 73.7 & 7.5 & 9.0 & 79.6 & 11.6 & 11.6 \\
\hline
\end{tabular}


Continued.

\begin{tabular}{|c|c|c|c|c|c|c|c|c|c|c|c|c|c|c|}
\hline \multicolumn{3}{|c|}{ FASRAC } & \multicolumn{12}{|c|}{ Official method } \\
\hline \multicolumn{3}{|c|}{ Apple } & \multicolumn{3}{|c|}{ Wheat flour } & \multicolumn{3}{|c|}{ Soy beans } & \multicolumn{3}{|c|}{ Spinach } & & Apple & \\
\hline $\begin{array}{c}\text { Recovery } \\
(\%)\end{array}$ & $\begin{array}{c}\mathrm{RSD}_{1}^{*} \\
(\%)\end{array}$ & $\begin{array}{c}\mathrm{RSD}_{2}^{* *} \\
(\%)\end{array}$ & $\begin{array}{c}\text { Recovery } \\
(\%)\end{array}$ & $\begin{array}{c}\mathrm{RSD}_{1}{ }^{*} \\
(\%)\end{array}$ & $\begin{array}{c}\mathrm{RSD}_{2}^{* *} \\
(\%)\end{array}$ & $\begin{array}{c}\text { Recovery } \\
(\%)\end{array}$ & $\begin{array}{c}\mathrm{RSD}_{1}^{*} \\
(\%)\end{array}$ & $\begin{array}{c}\mathrm{RSD}_{2}^{* *} \\
(\%)\end{array}$ & $\begin{array}{c}\text { Recovery } \\
(\%)\end{array}$ & $\begin{array}{c}\mathrm{RSD}_{1}{ }^{*} \\
(\%)\end{array}$ & $\begin{array}{c}\mathrm{RSD}_{2}^{* *} \\
(\%)\end{array}$ & $\begin{array}{c}\text { Recovery } \\
(\%)\end{array}$ & $\begin{array}{c}\mathrm{RSD}_{1}{ }^{*} \\
(\%)\end{array}$ & $\begin{array}{c}\mathrm{RSD}_{2}{ }^{* *} \\
(\%)\end{array}$ \\
\hline 79.4 & 7.2 & 7.2 & 86.4 & 4.4 & 8.4 & 84.2 & 13.5 & 14.3 & 80.9 & 4.7 & 10.1 & 85.5 & 6.0 & 8.0 \\
\hline 84.5 & 6.0 & 7.6 & 80.4 & 3.6 & 14.0 & 78.9 & 5.4 & 14.1 & 89.5 & 4.5 & 10.9 & 96.4 & 3.7 & 13.5 \\
\hline 78.0 & 6.1 & 6.1 & 82.2 & 4.6 & 14.9 & 75.9 & 5.4 & 8.5 & 82.2 & 6.8 & 6.8 & 86.6 & 4.9 & 7.6 \\
\hline 86.6 & 6.5 & 7.9 & 76.2 & 7.3 & 16.7 & 62.6 & 8.9 & 22.1 & 84.3 & 6.5 & 7.0 & 85.7 & 3.7 & 5.3 \\
\hline 85.8 & 1.9 & 5.8 & 79.5 & 2.5 & 11.9 & 65.5 & 5.5 & 19.8 & 83.2 & 2.5 & 6.8 & 91.7 & 2.2 & 5.9 \\
\hline 83.9 & 2.9 & 5.4 & 67.0 & 5.8 & 28.3 & 51.5 & 7.5 & 50.5 & 84.0 & 1.7 & 5.9 & 89.4 & 2.7 & 5.0 \\
\hline 71.3 & 8.7 & 9.1 & 64.7 & 5.4 & 11.2 & 30.4 & 9.2 & 13.2 & 66.1 & 8.3 & 11.3 & 75.7 & 4.5 & 6.6 \\
\hline 81.3 & 6.5 & 7.0 & 76.5 & 5.4 & 17.5 & 58.9 & 10.7 & 27.4 & 82.1 & 3.9 & 6.2 & 90.2 & 5.0 & 8.5 \\
\hline 84.0 & 4.5 & 6.5 & 79.9 & 5.3 & 14.5 & 69.4 & 8.2 & 15.0 & 79.5 & 8.5 & 8.5 & 93.0 & 3.2 & 7.8 \\
\hline 78.1 & 7.2 & 7.2 & 72.1 & 4.8 & 26.5 & 58.8 & 8.4 & 20.9 & 64.2 & 4.4 & 7.4 & 80.8 & 5.0 & 14.0 \\
\hline 84.8 & 2.9 & 4.8 & 90.6 & 6.8 & 16.6 & 81.2 & 4.0 & 12.1 & 82.0 & 2.7 & 6.3 & 87.9 & 2.7 & 9.9 \\
\hline 80.2 & 3.7 & 4.8 & 83.1 & 1.1 & 4.2 & 80.0 & 2.7 & 7.7 & 77.7 & 3.5 & 3.5 & 85.8 & 3.5 & 4.7 \\
\hline 80.0 & 7.4 & 8.5 & 81.7 & 6.0 & 15.8 & 81.6 & 10.3 & 13.9 & 81.9 & 4.4 & 7.2 & 86.0 & 2.8 & 4.5 \\
\hline 84.4 & 4.5 & 5.6 & 80.6 & 1.5 & 11.3 & 73.9 & 4.7 & 14.4 & 85.2 & 1.9 & 6.5 & 87.6 & 2.4 & 4.9 \\
\hline 81.3 & 3.6 & 6.9 & 81.7 & 2.0 & 13.4 & 77.5 & 7.5 & 10.1 & 83.3 & 3.2 & 4.9 & 88.5 & 3.0 & 3.7 \\
\hline 83.2 & 4.2 & 8.3 & 81.6 & 4.8 & 14.2 & 80.6 & 2.5 & 8.1 & 86.5 & 3.4 & 7.0 & 89.3 & 3.4 & 7.1 \\
\hline 86.2 & 9.2 & 12.5 & 84.8 & 8.8 & 26.2 & 77.4 & 5.8 & 14.7 & 83.4 & 8.0 & 10.9 & 88.8 & 10.0 & 10.5 \\
\hline 84.4 & 3.7 & 4.9 & 81.4 & 4.6 & 15.0 & 77.9 & 3.5 & 15.1 & 86.6 & 4.6 & 8.9 & 89.7 & 4.2 & 7.1 \\
\hline 76.7 & 4.3 & 4.4 & 81.5 & 2.3 & 8.8 & 74.9 & 6.3 & 10.8 & 73.2 & 4.5 & 5.5 & 77.3 & 1.9 & 12.3 \\
\hline 80.9 & 6.2 & 6.8 & 84.5 & 5.0 & 12.6 & 82.4 & 5.8 & 20.5 & 80.2 & 3.8 & 7.9 & 87.0 & 3.3 & 7.5 \\
\hline 84.0 & 5.4 & 6.0 & 85.9 & 3.3 & 16.0 & 82.4 & 5.5 & 15.3 & 89.0 & 5.8 & 8.2 & 90.7 & 4.5 & 9.6 \\
\hline 84.0 & 6.3 & 7.0 & 84.8 & 7.0 & 16.7 & 81.3 & 4.5 & 11.3 & 86.5 & 3.3 & 8.3 & 89.4 & 4.2 & 6.3 \\
\hline 81.3 & 2.7 & 5.6 & 86.1 & 1.7 & 14.9 & 84.8 & 2.0 & 12.0 & 88.0 & 4.6 & 8.1 & 94.0 & 17.3 & 17.9 \\
\hline 84.1 & 2.5 & 3.6 & 83.5 & 5.9 & 11.5 & 81.0 & 3.7 & 7.4 & 86.9 & 2.9 & 6.5 & 89.0 & 4.8 & 5.7 \\
\hline 81.6 & 4.9 & 4.9 & 75.2 & 2.3 & 10.0 & 60.7 & 11.0 & 17.3 & 59.6 & 5.5 & 10.1 & 86.1 & 2.3 & 5.0 \\
\hline 87.7 & 4.8 & 9.6 & 78.4 & 2.8 & 13.8 & 68.1 & 11.6 & 22.7 & 84.9 & 3.0 & 5.3 & 90.9 & 3.8 & 7.3 \\
\hline 83.7 & 5.4 & 7.9 & 82.5 & 7.2 & 18.5 & 79.0 & 2.8 & 18.3 & 87.8 & 6.2 & 13.8 & 92.4 & 2.8 & 7.0 \\
\hline 89.8 & 4.6 & 6.6 & 87.1 & 5.2 & 10.7 & 93.8 & 7.8 & 12.0 & 90.5 & 4.5 & 13.9 & 97.5 & 5.1 & 16.2 \\
\hline 82.7 & 3.3 & 6.0 & 88.0 & 4.5 & 25.6 & 88.9 & 5.8 & 19.5 & 87.2 & 8.7 & 11.0 & 88.5 & 4.6 & 7.9 \\
\hline 84.1 & 2.2 & 6.3 & 81.7 & 7.6 & 9.7 & 78.1 & 6.6 & 11.4 & 86.5 & 8.3 & 10.3 & 87.6 & 6.3 & 7.0 \\
\hline 82.1 & 2.3 & 5.2 & 86.9 & 2.6 & 9.6 & 86.8 & 2.0 & 9.1 & 88.4 & 3.9 & 7.8 & 91.8 & 5.1 & 6.0 \\
\hline 81.7 & 5.8 & 6.4 & 78.6 & 3.7 & 6.9 & 72.8 & 5.6 & 11.3 & 86.3 & 3.2 & 3.7 & 87.7 & 2.9 & 4.5 \\
\hline 84.1 & 2.9 & 6.0 & 76.7 & 5.0 & 16.2 & 63.6 & 5.3 & 15.2 & 86.1 & 3.9 & 4.0 & 90.7 & 5.8 & 7.5 \\
\hline 82.9 & 2.1 & 4.7 & 86.7 & 1.6 & 10.2 & 80.4 & 3.6 & 11.8 & 84.1 & 2.9 & 4.9 & 89.6 & 2.5 & 3.4 \\
\hline 84.8 & 5.4 & 5.7 & 81.5 & 6.2 & 14.4 & 79.5 & 4.4 & 13.5 & 85.4 & 4.0 & 4.1 & 84.6 & 3.3 & 7.4 \\
\hline 82.0 & 5.4 & 7.8 & 83.1 & 5.1 & 10.0 & 77.9 & 4.7 & 12.9 & 83.3 & 6.3 & 7.4 & 91.5 & 5.8 & 5.8 \\
\hline 81.9 & 3.4 & 4.8 & 82.8 & 2.8 & 11.5 & 73.0 & 2.3 & 10.2 & 79.4 & 2.1 & 5.3 & 86.5 & 2.5 & 5.5 \\
\hline 82.6 & 3.2 & 4.8 & 75.9 & 1.9 & 12.0 & 68.3 & 2.7 & 14.1 & 85.1 & 2.1 & 5.9 & 88.6 & 2.5 & 4.3 \\
\hline 82.5 & 5.2 & 6.5 & 87.6 & 6.7 & 19.8 & 84.8 & 2.4 & 6.2 & 80.9 & 8.2 & 11.3 & 86.7 & 3.2 & 6.6 \\
\hline 82.9 & 7.8 & 12.2 & 82.0 & 9.3 & 14.2 & 72.7 & 6.9 & 10.2 & 85.5 & 5.7 & 7.2 & 84.2 & 6.6 & 7.6 \\
\hline 82.4 & 3.8 & 6.4 & 80.9 & 2.9 & 10.8 & 72.5 & 2.9 & 12.8 & 83.1 & 2.1 & 5.2 & 87.7 & 2.8 & 5.1 \\
\hline 81.6 & 5.0 & 5.5 & 76.7 & 4.7 & 8.4 & 73.8 & 3.6 & 12.4 & 84.5 & 2.0 & 5.6 & 84.9 & 3.2 & 3.8 \\
\hline 84.6 & 5.4 & 6.6 & 81.6 & 5.6 & 12.6 & 76.1 & 4.4 & 9.7 & 85.9 & 2.8 & 6.0 & 87.7 & 5.5 & 6.3 \\
\hline 70.0 & 3.1 & 14.0 & 85.0 & 5.4 & 8.6 & 78.7 & 5.3 & 8.6 & 82.1 & 1.9 & 2.9 & 68.0 & 10.6 & 14.7 \\
\hline 85.9 & 2.0 & 7.6 & 78.5 & 3.8 & 11.4 & 68.1 & 5.5 & 16.6 & 84.5 & 3.3 & 4.0 & 88.5 & 3.8 & 4.4 \\
\hline 76.4 & 9.1 & 9.1 & 80.0 & 4.5 & 18.4 & 65.9 & 5.2 & 19.5 & 83.1 & 6.9 & 10.6 & 87.0 & 6.6 & 8.8 \\
\hline 80.3 & 4.7 & 5.3 & 86.8 & 2.9 & 17.7 & 80.5 & 4.8 & 19.8 & 88.1 & 5.7 & 13.1 & 89.4 & 3.1 & 7.1 \\
\hline 80.2 & 9.3 & 9.3 & 82.4 & 10.9 & 25.9 & 81.9 & 7.6 & 18.6 & 88.6 & 6.0 & 11.8 & 88.6 & 2.7 & 8.5 \\
\hline 82.0 & 4.2 & 7.5 & 85.4 & 3.2 & 13.9 & 82.6 & 10.0 & 15.1 & 87.6 & 4.6 & 5.5 & 89.2 & 5.9 & 7.6 \\
\hline 79.8 & 7.3 & 7.3 & 69.0 & 5.5 & 13.5 & 49.1 & 8.0 & 24.1 & 64.4 & 7.5 & 9.2 & 82.3 & 3.8 & 5.9 \\
\hline 80.5 & 14.6 & 14.6 & 68.7 & 5.7 & 19.4 & 69.2 & 5.8 & 15.5 & 82.9 & 5.2 & 7.0 & 83.3 & 3.8 & 11.1 \\
\hline 81.7 & 6.5 & 6.5 & 86.2 & 5.2 & 21.0 & 81.2 & 5.3 & 19.8 & 88.2 & 7.1 & 13.4 & 90.9 & 3.4 & 9.4 \\
\hline 80.7 & 5.9 & 7.5 & 67.2 & 8.6 & 16.8 & 46.2 & 16.1 & 27.7 & 64.0 & 11.0 & 11.0 & 82.7 & 6.9 & 6.9 \\
\hline 82.1 & 3.7 & 5.6 & 86.6 & 5.4 & 13.6 & 79.5 & 3.6 & 17.5 & 90.1 & 2.6 & 8.7 & 92.1 & 3.1 & 8.5 \\
\hline 79.5 & 5.5 & 6.4 & 71.0 & 3.2 & 5.8 & 63.9 & 7.2 & 14.0 & 72.5 & 3.7 & 7.1 & 87.3 & 4.2 & 4.9 \\
\hline 83.5 & 3.6 & 6.5 & 85.5 & 4.7 & 13.4 & 78.5 & 5.1 & 14.3 & 84.9 & 3.6 & 5.9 & 89.9 & 2.3 & 3.9 \\
\hline 81.6 & 3.3 & 5.7 & 82.8 & 4.7 & 13.4 & 78.2 & 4.3 & 12.2 & 86.5 & 2.5 & 4.0 & 89.0 & 2.6 & 4.0 \\
\hline 82.9 & 6.3 & 9.8 & 79.4 & 5.4 & 21.7 & 72.6 & 7.1 & 19.6 & 87.4 & 3.7 & 9.8 & 92.0 & 5.0 & 5.8 \\
\hline 75.3 & 3.5 & 3.7 & 76.7 & 3.5 & 21.1 & 67.3 & 4.1 & 15.8 & 83.2 & 4.6 & 7.5 & 80.0 & 3.9 & 8.1 \\
\hline 83.6 & 3.5 & 5.1 & 82.2 & 5.6 & 16.1 & 70.0 & 5.9 & 18.7 & 87.6 & 2.9 & 6.1 & 89.3 & 5.1 & 6.1 \\
\hline 84.1 & 8.5 & 8.5 & 86.4 & 6.2 & 8.4 & 82.6 & 7.3 & 10.1 & 84.3 & 4.0 & 6.4 & 87.0 & 1.4 & 5.5 \\
\hline 84.3 & 4.0 & 6.3 & 82.7 & 1.8 & 14.9 & 77.1 & 3.1 & 14.4 & 89.5 & 3.5 & 5.6 & 91.2 & 4.0 & 7.6 \\
\hline 80.7 & 3.5 & 6.1 & 78.9 & 4.1 & 19.5 & 66.3 & 5.1 & 16.5 & 75.4 & 4.9 & 9.9 & 87.6 & 2.3 & 7.9 \\
\hline 81.8 & 6.2 & 7.1 & 85.7 & 1.5 & 10.2 & 80.9 & 4.2 & 12.5 & 87.5 & 2.3 & 6.8 & 89.8 & 3.6 & 4.8 \\
\hline 82.6 & 3.6 & 8.1 & 81.0 & 5.5 & 16.3 & 83.4 & 9.3 & 14.9 & 85.4 & 5.4 & 8.4 & 88.5 & 3.3 & 7.3 \\
\hline 84.1 & 4.5 & 7.7 & 78.7 & 6.1 & 14.2 & 67.4 & 6.9 & 18.0 & 84.9 & 3.9 & 5.2 & 90.5 & 5.1 & 6.3 \\
\hline 79.2 & 2.2 & 5.5 & 89.9 & 5.2 & 18.4 & 77.6 & 3.5 & 11.9 & 82.1 & 2.5 & 5.5 & 92.8 & 4.3 & 8.3 \\
\hline 82.5 & 4.6 & 5.7 & 83.4 & 6.9 & 9.9 & 82.2 & 6.9 & 10.3 & 86.7 & 5.1 & 5.1 & 88.6 & 5.1 & 5.6 \\
\hline 82.2 & 4.6 & 9.2 & 84.1 & 5.8 & 10.6 & 86.9 & 3.9 & 11.0 & 91.0 & 6.4 & 8.3 & 95.2 & 4.4 & 4.4 \\
\hline
\end{tabular}


Table 1

\begin{tabular}{|c|c|c|c|c|c|c|c|c|c|c|c|c|}
\hline \multirow{3}{*}{ No. } & \multirow{3}{*}{ Pesticides } & \multirow{3}{*}{$\begin{array}{l}\text { MRM } \\
\text { transitions } \\
\quad(\mathrm{m} / \mathrm{z})\end{array}$} & \multirow{3}{*}{$\begin{array}{c}\mathrm{RT} \\
(\mathrm{min})\end{array}$} & \multicolumn{9}{|c|}{ FASRAC } \\
\hline & & & & \multicolumn{3}{|c|}{ Wheat flour } & \multicolumn{3}{|c|}{ Soy beans } & \multicolumn{3}{|c|}{ Spinach } \\
\hline & & & & $\begin{array}{c}\text { Recovery } \\
(\%)\end{array}$ & $\begin{array}{c}\mathrm{RSD}_{1}{ }^{*} \\
(\%)\end{array}$ & $\begin{array}{c}\mathrm{RSD}_{2}^{* *} \\
(\%)\end{array}$ & $\begin{array}{c}\text { Recovery } \\
(\%)\end{array}$ & $\begin{array}{c}\mathrm{RSD}_{1}{ }^{*} \\
(\%)\end{array}$ & $\begin{array}{c}\mathrm{RSD}_{2}^{* *} \\
(\%)\end{array}$ & $\begin{array}{c}\text { Recovery } \\
(\%)\end{array}$ & $\begin{array}{c}\mathrm{RSD}_{1}{ }^{*} \\
(\%)\end{array}$ & $\begin{array}{c}\mathrm{RSD}_{2}{ }^{* *} \\
(\%)\end{array}$ \\
\hline 277 & Thiobencarb & $100>72$ & 14.2 & 83.3 & 7.6 & 14.1 & 88.3 & 5.4 & 9.2 & 80.5 & 4.8 & 4.9 \\
\hline 278 & Tolclofos methyl & $265>250$ & 13.4 & 81.2 & 2.3 & 7.5 & 77.9 & 3.2 & 7.0 & 82.4 & 4.3 & 5.8 \\
\hline 279 & trans-Chlordane & $373>266$ & 15.5 & 86.1 & 7.0 & 10.1 & 80.0 & 9.0 & 13.8 & 80.2 & 4.0 & 9.0 \\
\hline 280 & trans-Nonachlor & $407>300$ & 17.0 & 76.9 & 5.9 & 14.2 & 72.1 & 12.3 & 12.3 & 78.8 & 5.0 & 7.5 \\
\hline 281 & Triadimefon & $208>111$ & 14.4 & 82.5 & 9.3 & 11.2 & 87.0 & 10.2 & 11.8 & 81.7 & 7.4 & 7.4 \\
\hline 282 & Triadimenol & $168>70$ & 15.2 & 80.6 & 10.4 & 13.8 & 79.2 & 10.8 & 14.2 & 82.7 & 4.9 & 12.0 \\
\hline 283 & Tri-allate & $268>184$ & 12.7 & 84.6 & 4.3 & 7.2 & 76.6 & 2.9 & 3.8 & 80.4 & 4.1 & 8.0 \\
\hline 284 & Triazophos & $161>134$ & 17.2 & 81.9 & 7.4 & 15.7 & 81.4 & 4.3 & 5.0 & 80.5 & 5.4 & 8.4 \\
\hline 285 & Tribufos & $202>113$ & 16.2 & 74.8 & 10.6 & 24.2 & 78.4 & 6.6 & 10.2 & 79.0 & 7.6 & 12.4 \\
\hline 286 & Trichlamide & $148>121$ & 15.6 & 77.7 & 4.6 & 10.0 & 73.1 & 8.8 & 11.7 & 70.2 & 8.0 & 11.9 \\
\hline 287 & Triflumizole & $278>73$ & 15.3 & 83.3 & 13.1 & 18.6 & 81.7 & 22.2 & 27.2 & 73.0 & 9.5 & 14.4 \\
\hline 288 & Trifluralin & $306>264$ & 11.0 & 86.9 & 5.5 & 11.0 & 85.1 & 3.5 & 6.5 & 74.2 & 4.3 & 5.3 \\
\hline 289 & Uniconazole-P & $234>165$ & 16.2 & 82.1 & 8.3 & 13.0 & 78.7 & 7.6 & 13.9 & 84.8 & 6.8 & 7.7 \\
\hline 290 & Vinclozolin & $285>212$ & 13.3 & 81.3 & 11.4 & 16.6 & 79.1 & 12.5 & 14.3 & 81.6 & 6.6 & 9.4 \\
\hline 291 & $\mathrm{XMC}$ & $122>107$ & 10.3 & 89.9 & 4.5 & 7.0 & 90.1 & 3.7 & 5.2 & 82.3 & 5.7 & 6.4 \\
\hline 292 & $Z$-Chlorfenvinphos & $323>267$ & 15.1 & 83.1 & 6.4 & 13.8 & 78.1 & 14.3 & 14.3 & 85.0 & 6.2 & 9.7 \\
\hline 293 & $Z$-Dimethylvinphos & $295>109$ & 14.2 & 83.7 & 5.4 & 8.5 & 82.5 & 8.1 & 9.4 & 78.0 & 6.1 & 6.1 \\
\hline 294 & $Z$-Metominostrobin & $191>160$ & 16.3 & 88.3 & 6.9 & 13.4 & 89.1 & 2.1 & 6.7 & 79.2 & 4.3 & 7.4 \\
\hline 295 & $Z$-Pyrifenox & $262>192$ & 15.5 & 74.8 & 12.4 & 21.1 & 76.4 & 11.4 & 16.9 & 74.5 & 6.8 & 6.8 \\
\hline 296 & $Z$-Pyriminobac-methyl & $302>256$ & 16.7 & 87.1 & 4.8 & 10.8 & 83.6 & 5.0 & 7.4 & 81.3 & 5.3 & 6.9 \\
\hline 297 & $\alpha$-BHC & $219>183$ & 11.4 & 82.8 & 6.2 & 12.2 & 75.8 & 4.3 & 10.8 & 81.9 & 3.5 & 6.2 \\
\hline 298 & $\alpha$-Endosulfan & $241>206$ & 15.8 & 72.1 & 31.5 & 36.3 & 77.5 & 35.8 & 39.6 & 90.9 & 6.1 & 11.3 \\
\hline 299 & $\beta-\mathrm{BHC}$ & $219>183$ & 11.9 & 80.4 & 10.7 & 23.8 & 79.0 & 9.4 & 13.4 & 84.4 & 7.0 & 10.2 \\
\hline 300 & $\beta$-Endosulfan & $241>206$ & 16.9 & 75.6 & 11.4 & 30.2 & 75.2 & 15.7 & 29.4 & 84.1 & 9.2 & 12.7 \\
\hline 301 & $\gamma$-BHC & $219>183$ & 12.7 & 82.4 & 8.9 & 12.0 & 82.8 & 6.5 & 10.0 & 81.2 & 6.5 & 9.2 \\
\hline 302 & $\delta$-BHC & $219>183$ & 12.1 & 84.6 & 6.1 & 14.6 & 75.0 & 11.4 & 14.4 & 81.2 & 11.2 & 11.2 \\
\hline
\end{tabular}

$*: \mathrm{RSD}_{1}$ of repeatability

**: $\mathrm{RSD}_{2}$ of within-run reproducibility

Table 2. Summary of result comparison table

FASRAC

\begin{tabular}{|c|c|c|c|c|c|c|c|c|c|}
\hline Category & Pesticides & $\begin{array}{c}70 \% \leqq \\
\text { Recovery } \\
\leqq 120 \%\end{array}$ & Percentage & $\begin{array}{l}\text { Repeatability } \\
(\text { RSD } \%)<25\end{array}$ & Percentage & $\begin{array}{l}\text { Within-run } \\
\text { reproducibility } \\
(\mathrm{RSD} \%)<30\end{array}$ & Percentage & $\begin{array}{c}\text { Meeting } \\
\text { all criteria }\end{array}$ & Percentage \\
\hline Wheat flour & 302 & 291 & $96 \%$ & 298 & $99 \%$ & 295 & $98 \%$ & 285 & $94 \%$ \\
\hline Soy beans & 302 & 281 & $93 \%$ & 299 & $99 \%$ & 299 & $99 \%$ & 278 & $92 \%$ \\
\hline Spinach & 302 & 284 & $94 \%$ & 302 & $100 \%$ & 302 & $100 \%$ & 284 & $94 \%$ \\
\hline Apple & 302 & 284 & $94 \%$ & 302 & $100 \%$ & 302 & $100 \%$ & 284 & $94 \%$ \\
\hline \multicolumn{10}{|c|}{ Official method } \\
\hline Category & Pesticides & $\begin{array}{c}70 \% \leqq \\
\text { Recovery } \\
\leqq 120 \%\end{array}$ & Percentage & $\begin{array}{l}\text { Repeatability } \\
(\mathrm{RSD} \%)<25\end{array}$ & Percentage & $\begin{array}{l}\text { Within-run } \\
\text { reproducibility } \\
(\mathrm{RSD} \%)<30\end{array}$ & Percentage & $\begin{array}{c}\text { Meeting } \\
\text { all criteria }\end{array}$ & Percentage \\
\hline Wheat flour & 302 & 277 & $92 \%$ & 302 & $100 \%$ & 291 & $96 \%$ & 273 & $90 \%$ \\
\hline Soy beans & 302 & 232 & $77 \%$ & 300 & $99 \%$ & 293 & $97 \%$ & 229 & $76 \%$ \\
\hline Spinach & 302 & 281 & $93 \%$ & 302 & $100 \%$ & 302 & $100 \%$ & 281 & $93 \%$ \\
\hline Apple & 302 & 284 & $94 \%$ & 302 & $100 \%$ & 300 & $99 \%$ & 283 & $94 \%$ \\
\hline
\end{tabular}

度（70～ $120 \%)$ ，併行精度（RSD \%<25\%）および室内 精度（RSD\%<30\%）に適合したのに対し，手作業の前 処理では適合した農薬は 229 農薬であった。

真度で両前処理を比較すると, 大豆に対して FASRAC の前処理では 281 農薬が目標值 $(70 〜 120 \%)$ に適合した のに対し，手作業の前処理では 232 農薬と差が見られ，小 麦粉でもFASRACの前処理の方が目標值（70〜120\%） に適合した農薬が 14 農薬多かった. 手作業の前処理の真 度の低下を引き起こした要因としては, 塩析工程において
FASRACではアセトニトリルによる再抽出を 2 回行なっ ているのに対して, 手作業では再抽出を行わないことが大 きいと考えられた。 これは小麦粉や大豆のほうがほうれん 草やりんごよりも脂質を多く含み, その影響で分配率が変 化し, 主に有機塩素系農薬や構造中にフェニル基を持つ農 薬など親油性が高い農薬に影響を与えたためと考えられ た. 手作業の前処理マニュアルおいてこの点を改善すれ ば，真度の目標值を達成することが可能であると考えられ た.よって, 穀類や豆類について, FASRACの前処理は 
Continued.

\begin{tabular}{|c|c|c|c|c|c|c|c|c|c|c|c|c|c|c|}
\hline \multicolumn{3}{|c|}{ FASRAC } & \multicolumn{12}{|c|}{ Official method } \\
\hline \multicolumn{3}{|c|}{ Apple } & \multicolumn{3}{|c|}{ Wheat flour } & \multicolumn{3}{|c|}{ Soy beans } & \multicolumn{3}{|c|}{ Spinach } & \multicolumn{3}{|c|}{ Apple } \\
\hline $\begin{array}{c}\text { Recovery } \\
(\%)\end{array}$ & $\begin{array}{c}\mathrm{RSD}_{1}{ }^{*} \\
(\%)\end{array}$ & $\begin{array}{c}\mathrm{RSD}_{2}^{* *} \\
(\%)\end{array}$ & $\begin{array}{c}\text { Recovery } \\
(\%)\end{array}$ & $\begin{array}{c}\mathrm{RSD}_{1}{ }^{*} \\
(\%)\end{array}$ & $\begin{array}{c}\mathrm{RSD}_{2}{ }^{* *} \\
(\%)\end{array}$ & $\begin{array}{c}\text { Recovery } \\
(\%)\end{array}$ & $\begin{array}{c}\mathrm{RSD}_{1}{ }^{*} \\
(\%)\end{array}$ & $\begin{array}{c}\mathrm{RSD}_{2}^{* *} \\
(\%)\end{array}$ & $\begin{array}{c}\text { Recovery } \\
(\%)\end{array}$ & $\begin{array}{c}\mathrm{RSD}_{1}{ }^{*} \\
(\%)\end{array}$ & $\begin{array}{c}\mathrm{RSD}_{2}^{* *} \\
(\%)\end{array}$ & $\begin{array}{c}\text { Recovery } \\
(\%)\end{array}$ & $\begin{array}{c}\mathrm{RSD}_{1}{ }^{*} \\
(\%)\end{array}$ & $\begin{array}{c}\mathrm{RSD}_{2}{ }^{* *} \\
(\%)\end{array}$ \\
\hline 82.9 & 3.7 & 4.4 & 81.1 & 6.0 & 12.8 & 80.6 & 4.1 & 5.7 & 84.3 & 2.6 & 6.4 & 88.3 & 1.5 & 2.8 \\
\hline 82.6 & 4.4 & 8.2 & 82.2 & 4.6 & 16.7 & 77.2 & 3.7 & 13.7 & 88.1 & 1.2 & 5.9 & 89.1 & 4.0 & 5.6 \\
\hline 84.2 & 8.0 & 8.0 & 78.9 & 5.8 & 22.3 & 62.6 & 12.0 & 17.9 & 83.5 & 5.7 & 6.5 & 90.2 & 4.7 & 5.6 \\
\hline 83.3 & 4.4 & 8.1 & 75.7 & 5.7 & 17.9 & 58.3 & 6.4 & 20.4 & 84.0 & 4.6 & 6.6 & 90.2 & 6.6 & 6.7 \\
\hline 87.2 & 6.5 & 10.3 & 82.6 & 13.0 & 17.0 & 82.5 & 10.6 & 12.5 & 89.8 & 6.1 & 6.1 & 89.6 & 3.7 & 7.4 \\
\hline 83.9 & 8.0 & 8.0 & 81.3 & 5.8 & 12.3 & 85.3 & 12.1 & 12.3 & 94.7 & 2.1 & 5.9 & 89.3 & 4.3 & 6.4 \\
\hline 81.1 & 3.7 & 5.1 & 77.1 & 5.8 & 18.0 & 69.2 & 4.8 & 15.3 & 86.0 & 5.9 & 7.1 & 88.6 & 4.8 & 5.6 \\
\hline 82.1 & 4.1 & 4.1 & 83.5 & 6.1 & 13.2 & 81.9 & 4.9 & 13.3 & 83.9 & 4.3 & 4.7 & 89.4 & 2.7 & 4.4 \\
\hline 79.5 & 15.2 & 15.2 & 76.2 & 8.5 & 17.4 & 73.1 & 15.5 & 25.4 & 80.7 & 5.1 & 12.2 & 90.3 & 8.2 & 10.5 \\
\hline 71.2 & 5.8 & 7.2 & 75.7 & 5.1 & 18.1 & 68.3 & 6.1 & 19.3 & 68.0 & 3.6 & 8.1 & 78.1 & 3.5 & 8.0 \\
\hline 75.5 & 17.2 & 17.2 & 77.3 & 20.8 & 29.2 & 62.9 & 16.6 & 19.3 & 74.0 & 10.6 & 10.9 & 69.2 & 7.7 & 27.1 \\
\hline 78.6 & 2.6 & 4.5 & 84.8 & 2.7 & 13.2 & 80.6 & 2.1 & 8.2 & 80.9 & 4.7 & 6.0 & 86.3 & 3.0 & 6.0 \\
\hline 82.8 & 5.3 & 6.0 & 81.8 & 11.5 & 14.9 & 80.3 & 10.2 & 24.4 & 89.6 & 5.3 & 7.8 & 91.6 & 5.1 & 7.8 \\
\hline 87.1 & 2.4 & 8.0 & 85.0 & 14.5 & 16.6 & 79.6 & 8.6 & 23.5 & 87.9 & 5.9 & 6.7 & 91.1 & 7.1 & 7.7 \\
\hline 85.3 & 3.2 & 4.4 & 89.2 & 1.0 & 10.7 & 86.3 & 3.0 & 10.3 & 84.8 & 5.2 & 5.9 & 88.5 & 2.7 & 3.3 \\
\hline 82.9 & 4.6 & 9.0 & 85.7 & 6.2 & 10.4 & 82.7 & 5.1 & 9.5 & 86.8 & 5.7 & 5.7 & 88.7 & 6.1 & 6.1 \\
\hline 79.6 & 5.5 & 5.5 & 83.3 & 4.3 & 15.6 & 81.5 & 4.4 & 9.0 & 86.4 & 3.3 & 5.4 & 89.4 & 3.0 & 6.3 \\
\hline 81.5 & 4.1 & 4.7 & 86.3 & 3.6 & 12.6 & 85.4 & 5.8 & 7.5 & 82.5 & 3.5 & 7.4 & 84.1 & 10.3 & 10.3 \\
\hline 64.0 & 7.3 & 21.7 & 75.1 & 14.0 & 23.2 & 72.1 & 8.6 & 20.4 & 78.7 & 6.6 & 9.6 & 69.8 & 9.9 & 17.9 \\
\hline 83.1 & 4.3 & 4.8 & 83.4 & 2.7 & 9.1 & 81.4 & 3.4 & 8.5 & 86.4 & 2.5 & 4.7 & 88.8 & 3.3 & 6.0 \\
\hline 77.6 & 6.2 & 8.1 & 83.7 & 1.7 & 18.0 & 73.0 & 4.3 & 15.4 & 89.6 & 5.6 & 10.2 & 87.2 & 2.0 & 9.6 \\
\hline 77.3 & 12.5 & 17.5 & 78.2 & 21.1 & 29.8 & 63.8 & 23.9 & 30.8 & 84.6 & 6.4 & 22.7 & 85.8 & 9.2 & 16.4 \\
\hline 83.1 & 6.3 & 11.5 & 83.9 & 7.2 & 18.1 & 77.1 & 8.1 & 16.6 & 86.4 & 3.7 & 10.4 & 91.7 & 3.5 & 7.3 \\
\hline 77.5 & 12.0 & 16.6 & 82.1 & 14.2 & 16.6 & 68.5 & 13.2 & 25.9 & 88.2 & 7.2 & 8.1 & 90.9 & 11.5 & 11.5 \\
\hline 84.1 & 3.5 & 7.2 & 91.2 & 6.4 & 14.7 & 76.8 & 8.7 & 18.7 & 88.7 & 6.7 & 8.4 & 90.6 & 5.9 & 6.1 \\
\hline 83.1 & 7.1 & 9.5 & 83.1 & 5.0 & 13.5 & 78.3 & 3.0 & 14.3 & 88.3 & 6.4 & 11.8 & 90.2 & 6.0 & 6.0 \\
\hline
\end{tabular}

手作業の前処理より優れ，より能力を発揮できる可能性が あることが示唆された。

精度のみで比較した場合は両前処理法において併行精 度, 室内精度ともに同等の結果が得られた。室内精度にお いては 302 対象農薬別に比較すると, FASRACでの分析 法の方がRSD\%が小さな值を示している農薬数は, 小麦 粉 199 農薬, 大豆 229 農薬, ほうれん草 142 農薬㧍よびり んご136農薬であった，特に小麦粉や大豆では，前述した 農薬の性状による真度への影響も大きいと考えられるが, 分析者間における手技の個人差を低減できる可能性も示唆 された。

したがって，新規自動前処理装置FASRACを用いた残 留農薬一斉分析法は, 作業の効率化, 省力化, 洗浄有機溶 媒を一切使用せず，分析者間における手技の個人差を低減 した分析法であり，「食品中に残留する農薬等に関する試 験法の妥当性評価ガイドライン」に準じて, 手作業（公定
法）と比較することにより，妥当性評価を実施した結果， 本法は手作業（公定法）と同等以上であることが確認され た。 今後は本研究で用いた検体以外でも妥当性評価を行 ない，より多種類の農産物において本法が有効であること を確認し，必要であれば本装置を含め改良していきたい．

\section{謝辞}

本研究にあたり，自動前処理装置FASRACの共同開発 にご尽力いただいたシステム・インスッルメンッ株式会社 の皆様に深く感謝申し上げます。

\section{文献}

1) Okuda, T., Yamada, T., Hatakeyama, O., Tobiishi, K., Kato, M., Kuroda, T. Japan Kokai Tokkyo Koho 5395847 (Jan. 7, 2013). 